\title{
Exposure to Silica, Arsenic, and Chromium (VI) in Cement Workers: A Probability Health Risk Assessment
}

\author{
Noor Haziqah Kamaludin ${ }^{1}$, Juliana Jalaludin ${ }^{1,3 *}$, Shamsul Bahri Mohd Tamrin ${ }^{1}$, \\ Abdah Md Akim², Tri Martiana ${ }^{3}$, Noeroel Widajati ${ }^{3}$
}

${ }^{1}$ Department of Environmental and Occupational Health, Faculty of Medicine and Health Science, 43400 Universiti Putra Malaysia (UPM), Serdang, Selangor, Malaysia

${ }^{2}$ Department of Biomedical Science, Faculty of Medicine and Health Science, 43400 Universiti Putra Malaysia (UPM), Serdang, Selangor, Malaysia

${ }^{3}$ Department of Occupational Health and Safety, Faculty of Public Health, Universitas Airlangga, 60115 Surabaya, East Java, Indonesia

\begin{abstract}
Cement mineral dust contains a variety of carcinogenic and non-carcinogenic substances. The study aimed to determine the probability of health risk among cement workers due to respirable silica ( $\mathrm{Si}$ ), arsenic (As), and chromium (Cr) VI dust exposure. A cross-sectional study was carried out among 123 cement workers. A personal air sampling pump was used to assess respirable cement dust exposure. Inductively coupled plasma mass spectrometry (ICP-MS) was used for As, and Cr analysis, and X-ray powder diffraction (XRD) was used for Si analysis. The Fractional Exhaled Nitric Oxide levels and lung function test were obtained by using NIOX MINO and Chestgraph H1-105 spirometer. Risk assessment was calculated by using the incremental lifetime cancer risk (ILCR) and non-cancerous hazard quotient (HQ). The geometric mean and standard deviation of respirable Si and Cr dust concentrations were $5.27 \pm 2.36 \mathrm{mg} \mathrm{m}^{-3}$ and $1.53 \pm 2.47 \mathrm{mg} \mathrm{m}^{-3}$, respectively, in manufacturing workers. The mean concentration for As in administrative workers was $0.07 \pm 0.02 \mathrm{mg} \mathrm{m}^{-3}$. After controlling for confounders, the abnormalities of $\mathrm{FVC} \%$ predicted and $\mathrm{FEV}_{1} \%$ predicted were significantly associated with the respirable Si dust among cement workers $(\mathrm{OR}=6.913 ; \mathrm{CI}=1.965-24.322$ and $\mathrm{OR}=18.320 ; \mathrm{CI}=3.078-109.027$ ). FENO concentrations in administrative workers were significantly influenced by the exposure to respirable $\mathrm{Si}$ dust $\left(\mathrm{R}^{2}=\right.$ $0.584, \mathrm{p}=0.006)$. Manufacturing workers had a high probability of getting cancer due to Si exposure in cement respirable dust at $29.81 \times 10^{-4}$ times compared to administrative workers at $4.14 \times 10^{-4}$ times. After reducing for control factors, the probability of manufacturing workers reduced to $0.45 \times 10^{-4}$ times. As and $\mathrm{Cr}$ (VI) dust exposures among cement workers had a probability of cancer risk of $7.49 \times 10^{-4}$ and $44.09 \times 10^{-4}$ times, respectively, after reducing for control factors. The non-cancerous disease risk of the workers from exposure to cement mineral dust exceeded the acceptance limit (HQ > 1). Cement workers were at high risk of developing cancerous and non-cancerous diseases due to exposure while working. Cement workers were highly exposed to respirable $\mathrm{Si}$, As, and $\mathrm{Cr}$ dust above the permissible exposure limit.
\end{abstract}

Keywords: Cement mineral dust; Incremental lifetime cancer risk (ILCR); Hazard quotient (HQ); Health risk assessment.

\section{INTRODUCTION}

The continued growth of developing countries is causing a high demand for road and building construction materials. It was estimated that in the year 2020, the production of cement would be 4.41 Gtonne year $^{-1}$, and in the year 2030 , it will increase to 5.00 Gtonne year ${ }^{-1}$ (WWF, 2008). The total estimated annual production of cement in Malaysia by eight major cement industries are 40.2 Mtonne year ${ }^{-1}$

\footnotetext{
* Corresponding author.

E-mail address: juliana@upm.edu.my
}

(MyCC, 2017). Meanwhile, 7.2 Mtonne year ${ }^{-1}$ is an annual cement production capacity by Cement Industries of Malaysia Berhad (CIMA) which constitutes as the secondlargest cement producers in Malaysia (MyCC, 2017). This cement industry is one of the largest cement plants in Malaysia, which having quarries activity in the plant and produces about $18 \%$ of the national cement production capacity (MyCC, 2017).

Portland cement is the most common type of cement used with the mechanism of a hydraulic binder. The input raw materials used in cement production contain several trace element concentrations, such as cadmium $(\mathrm{Cd})$, copper $(\mathrm{Cu})$, zinc $(\mathrm{Zn})$, nickel $(\mathrm{Ni})$, cobalt $(\mathrm{Co})$, chromium $(\mathrm{Cr})$, arsenic (As), and lead (Pb) (Achternbosch et al., 2005). The chemical 
composition in Portland cement contains high levels of silica $(\mathrm{Si})$, aluminum $(\mathrm{Al})$, calcium $(\mathrm{Ca})$, and magnesium $(\mathrm{Mg})$ (Bae et al., 2017). Cement manufacturing contributes to non-volatile metal dust emission, which includes $\mathrm{Cr}$, As, $\mathrm{Ni}$, $\mathrm{Al}$, and manganese (Mn) (DOE, 2014). Si is readily found in the raw materials of the cement production process, including sand grounding, quartz crushing, and material refraction (IARC, 1997). The cement production process uses different sources of raw material containing various types of trace element concentrations from the natural mineral contained in limestone, clay, rock, chalk, and shale.

The Total Weight Average for eight hours working time (TWA-8) for $\mathrm{Si}$ crystalline quartz according to the Occupational Safety and Health Act 1994 (Act 514) is $0.1 \mathrm{mg} \mathrm{m}^{-3}$ for a respirable fraction as prescribed under scheduled one of the Use and Standards of Exposure of Chemicals Hazardous to Health Regulation 2000 (Malaysia, 2011). Arsenic (As) compound can be found in the form of organic and inorganic form in which the inorganic form is highly toxic to humans compared to organic form (WHO, 2018). Occupational exposure to As dust mainly occurs through the inhalation of total inorganic As dust (IARC, 2012). The TWA- 8 for As is $0.01 \mathrm{mg} \mathrm{m}^{-3}$ prescribed under scheduled one of the Use and Standards of Exposure of Chemicals Hazardous to Health Regulation 2000 (Malaysia, 2011). The permissible exposure limit for the TWA-8 for $\mathrm{Cr}$ metal and compound is $0.5 \mathrm{mg} \mathrm{m}^{-3}, \mathrm{Cr}$ (III) is $0.5 \mathrm{mg} \mathrm{m}^{-3}$ and $\mathrm{Cr}(\mathrm{VI})$ is $0.01 \mathrm{mg} \mathrm{m}^{-3}$ as prescribed in schedule one of the Use and Standards of Exposure of Chemicals Hazardous to Health Regulation 2000 (Malaysia, 2011). Cr (III) naturally exists in rocks and soils, and essentially in a small amount to the human body. However, this Cr (III) can easily be transformed into $\mathrm{Cr}$ (VI) by oxidation process in the cement production (Bae et al., 2017).

Crystalline Si dust (quartz), As, and Cr (VI) compounds have been classified as group 1 carcinogens to human health by the International Agency for Research on Cancer (IARC), where the primary target organ is the lung (IARC, 2012). This classification as group 1 is due to sufficient evidence of carcinogenicity in humans, where there is a positive association of exposure to the agent and cancer studies (IARC, 2019). The incremental lifetime cancer risk (ILCR) is a calculation to determine the potential carcinogenic health effect as the result of exposure to a specific hazardous material (Bleam, 2012). The hazard quotient (HQ) is a calculation to determine the potential non-cancer risk health effect among cement workers. The ILCR and HQ calculation formula have Stated by the IARC and the United States Environmental Protection Agency (U.S. EPA, 1989).

The ILCR calculation formula was derived from the lifetime average daily dose (LADD) and the carcinogen toxicity that have been presented in cancer slope factors (SF) (U.S. EPA, 2011). The U.S. EPA has built an integrated risk information system (IRIS) to collect and gather all research information that produced high-quality, evidence-based assessment involving the chemical toxicity on human health. The IRIS information is used as the SF in ILCR as a reference source in estimating the increase of cancer risk from inhalation of lifetime exposure and can be derived from inhalation unit risk (IUR) (U.S. EPA, 2011). The LADD is an assumption of body burden accumulated with the hazardous material over a lifetime by considering individual exposure factors. The exposure factors among individuals vary according to human behavior and characteristic such as exposure concentration, breathing rate, exposure frequency and body weight (U.S. EPA, 2011). However, the U.S. EPA has specified for a human averaging lifetime is 70 years and averaging exposure duration of workers is 20 years.

The HQ calculation formula was derived from the average daily dose (ADD) to the toxicity of the substance (U.S. EPA, 2011). The toxicity of the substance is represented in the reference dose (RfD) which the low dose extrapolated end-point strictly limited to non-carcinogenic toxicants. The RfD data was derived from no observed adverse effect level (NOAEL), lowest observed adverse effect level (LOAEL), or benchmark concentration (U.S. EPA, 2011).

A great deal of attention in the cement industry has focused on the dusty emissions that contribute to severe health effects. People who were exposed to cement dust have been studied and showed adverse respiratory health effects and an increased frequency of respiratory problems (Al-Neaimi et al., 2001). Respirable to Si dust in the activities such as sandblasting, stone crushers, and quarrying in cement industries can contribute to respiratory diseases such as silicosis, chronic airway obstruction and bronchitis (Oyinloye, 2015). Silicosis can be described in three types of exposure to respirable dust with acute exposure, accelerated exposure and chronic exposure (Balakrishnan et al., 2019). Acute silicosis relatively short duration of exposure within a few months or years with a high content of crystalline Si. Accelerated silicosis where the exposure to respirable crystalline Si dust is more than five years to 15 years while the common exposure is chronic silicosis where the exposure usually more than 20 years (Balakrishnan et al., 2019). According to the International Programme on Chemical Safety, inhalation of As dust may cause rhinitis, pharyngitis, laryngitis, and trachea bronchitis, and tracheal and bronchial hemorrhage and may lead to complicating severe cases. Besides, the exposure to As dust also may show a symptom such as a cough, chest pain, difficulty breathing, headache, and in a long-term exposure may show a symptom of nasal sputum perforation (U.S. EPA, 2012). Inhalation of dust containing $\mathrm{Cr}$ may last several years in the lungs with symptoms of cough, shortness of breath, wheezing, and asthma (ATSDR, 2012). The exposure to $\mathrm{Cr}$ dust in the occupational settings with a concentration greater than or equal to $0.002 \mathrm{mg} \mathrm{m}^{-3}$ causing nasal irritation and decreased pulmonary function and leading to pulmonary edema, bronchitis and acute bronchopneumonia (ATSDR, 2012).

The use of workers' biomarkers can precisely indicate the occupational diseases regarding dust exposure and assist medical practitioners in making treatment decisions (Kim et al., 2017; Kamaludin et al., 2018b). It was estimated that 830 out of $10,000\left(830 \times 10^{-4}\right)$ exposed cement manufacturing workers in Tehran had an excess lifetime risk of mortality caused by lung cancer (Rice et al., 2001). Studies on Cr (VI) exposure have found high cancer risk among respondents 
(Fang et al., 2013; Othman et al., 2016; Sulong et al., 2017; $\mathrm{Xu}$ et al., 2019). Industrial contributes to $68.7 \%$ of arsenic emission into the environment with $0.04 \times 10^{-4}$ times of cancer risk (Tsai et al., 2019). Controlling the exposure factors of crystalline Si dust can profoundly reduce the ILCR among workers (Yeheyis et al., 2012).

The American Thoracic Society (ATS) recommended the use of Fractional Exhaled Nitric Oxide (FENO) as a quantitative, non-invasive, simple and safe method for measuring airway inflammation biomarkers (ATS/ERS, 2005). FENO has been proposed as a useful biomarker in asthma patients (Frank et al., 1998; Kamaruddin et al., 2019). The presence of eosinophilic inflammation causes nitric oxide synthase 2A (NOS2A) to overproduce nitric oxide. NOS2A, the inducible nitric oxide synthase (NOS) isoform implicated in asthma (Maarsingh et al., 2008; Malerba et al., 2014). Eosinophilic inflammation generates nitric oxide (NO), a fraction of which can be measured during exhalation. Measurement of exhaled nitric oxide does not measure the production of nitric oxide in the lungs, but assesses the net output of the various nitric oxide production mechanisms minus the consumption of nitric oxide by numerous pathways across the airways (Nguyen et al., 2005). Asthma patients have high levels of nitric oxide in their exhaled breath and high levels of inducible nitric oxide synthase $\left(\mathrm{NOS}_{2}\right)$ enzyme expression in the epithelial cells of their airways, indicating the role of nitric oxide in asthma pathogenesis (Dweik et al., 2011).

The ATS prescribed for the normal airways for adults will exhale less than $25 \mathrm{ppb}$ of nitric oxide, where eosinophilic cell inflammation and corticosteroid responsiveness are less likely at this time (ATS/ERS, 2005). If the adult has exhaled nitric oxide in the concentration range of 25-50 ppb, this shows an intermediate allergy inflammation of the airway where there is a mild symptom and response of asthma (ATS/ERS, 2005). While the concentration of exhaled nitric oxide above $50 \mathrm{ppb}$ indicates that a person has significantly high allergic airway inflammation and eosinophilic cell inflammation (ATS/ERS, 2005). Symptomatic patients, responsiveness to corticosteroids, are likely and advisable in the clinical context. It is recommended for immediate treatment of asthma and to reduce the exposure of contaminants to air. A study of the cement industry in Kashmir, India, found that the exposed group had a significantly high concentration of exhaled nitric oxide, more than 50 ppb (Mehraj et al., 2013). ATS has recommended that factors that need to be considered when obtaining exhaled nitric oxide, including atopy, height, age, sex, respiratory tract infection, nitrate-containing food or diet, caffeine intake, alcohol, smoking, respiratory maneuver, physical activity, race, and anti-inflammation or allergy treatment, be considered.

Spirometry is a lung function test used to determine the severity or stage of the disease that patients will determine the appropriate improvement or response to treatment (Jones Medical, 2010). Although reading the lung function test is normal, occupational asthma may be present. Spirometric surveillance should be performed to represent an early stage of respiratory disease and as a complement to the biomarker outcome (Fell et al., 2010). The spirometer is a device used to test the level of lung function in expired and inspired volumes over time (Johns and Pierce, 2008). Vital Capacity (VC) is the maximum volume of air that can be exhaled or inspired by the maximum Forced Vital Capacity (FVC). Normal VC is equal to FVC except where there is obstruction of airflow. $\mathrm{FEV}_{1}$ is the Forced Expired Volume in the first second of maximum expiration after maximum inspiration. $\mathrm{FEV}_{1}$ is useful to measure how quickly the full lungs can be emptied. Peak Expiratory Flow (PEF) is the maximum expiratory flow rate and normally occurs early in the forced expiratory manoeuvre. $\mathrm{FEV}_{1} \%$ predicted indicates the obstructive level of the lung, while the $\mathrm{FVC} \%$ predicted indicates the restrictive level of the lung (ATS, 2015). According to the Workers Health Protection Programme (2013), the normal percentage of FVC\% predicted and $\mathrm{FEV}_{1} \%$ predicted concentration for workers should be equal to or greater than $80 \%$ and the normal percentage of $\mathrm{FEV}_{1} / \mathrm{FVC} \%$ predicted concentration for workers should be equal to or greater than $70 \%$. However, if the concentration percentage ratio is too high, which is greater than $120 \%$, abnormalities in the lung are also shown (Pakhale et al., 2009). Several factors may influence the lung function such as gender, height, age, weight, smoking status, race, air exposure, and respiratory disease (Ostrowski and Barud, 2006).

The objective of this study was to determine the probability of cancerous and non-cancerous disease risk among industrial cement workers due to exposure to respirable crystalline $\mathrm{Si}$, As, and $\mathrm{Cr}$ (VI) dust. A comparison was made between two groups of workers in the cement industry: manufacturing workers and administrative workers.

\section{METHODS}

\section{Study Design and Study Location}

This study is a cross-sectional study conducted on 72 male manufacturing workers in the cement industry as the directly exposed group and 51 male administrative staff in the cement industry as the indirectly exposed group. The study location was selected based on the prefecture of the surrounding environment of the cement industry, which has a clay rock quarry opposite its premises as in Fig. 1. The location is in Negeri Sembilan, Malaysia and near Banjaran Titiwangsa, where there is mountain rock soil suitable as a source of raw materials for cement production.

The sample were obtained from 12 March until 20 April 2018. However, for the respondent that received the treatment or using medication within 6 months before the sampling date, their biological sample were obtained on 18 and 19 June 2018. The mateorological data was obtained from mateorological department for Jempol district. Average ambient temperature recorded during this sampling time in Jempol is $32.8^{\circ} \mathrm{C}$ with the minimum and maximum temperature range of $31^{\circ} \mathrm{C}$ to $35^{\circ} \mathrm{C}$. The total average rainfall during daytime is $0.2 \mathrm{~mm}$ which almost considered as no rain during daytime. The average of humidity is $55.5 \%$ with $1.91 \mathrm{~m} \mathrm{~s}^{-1}$ average of wind speed. The average air temperature in the cement manufacturing premise is $33^{\circ} \mathrm{C}$ with lower relative humidity less than $20 \%$, meanwhile, the average air temperature in the cement office building is $23^{\circ} \mathrm{C}$ with $35 \%$ relative humidity. 

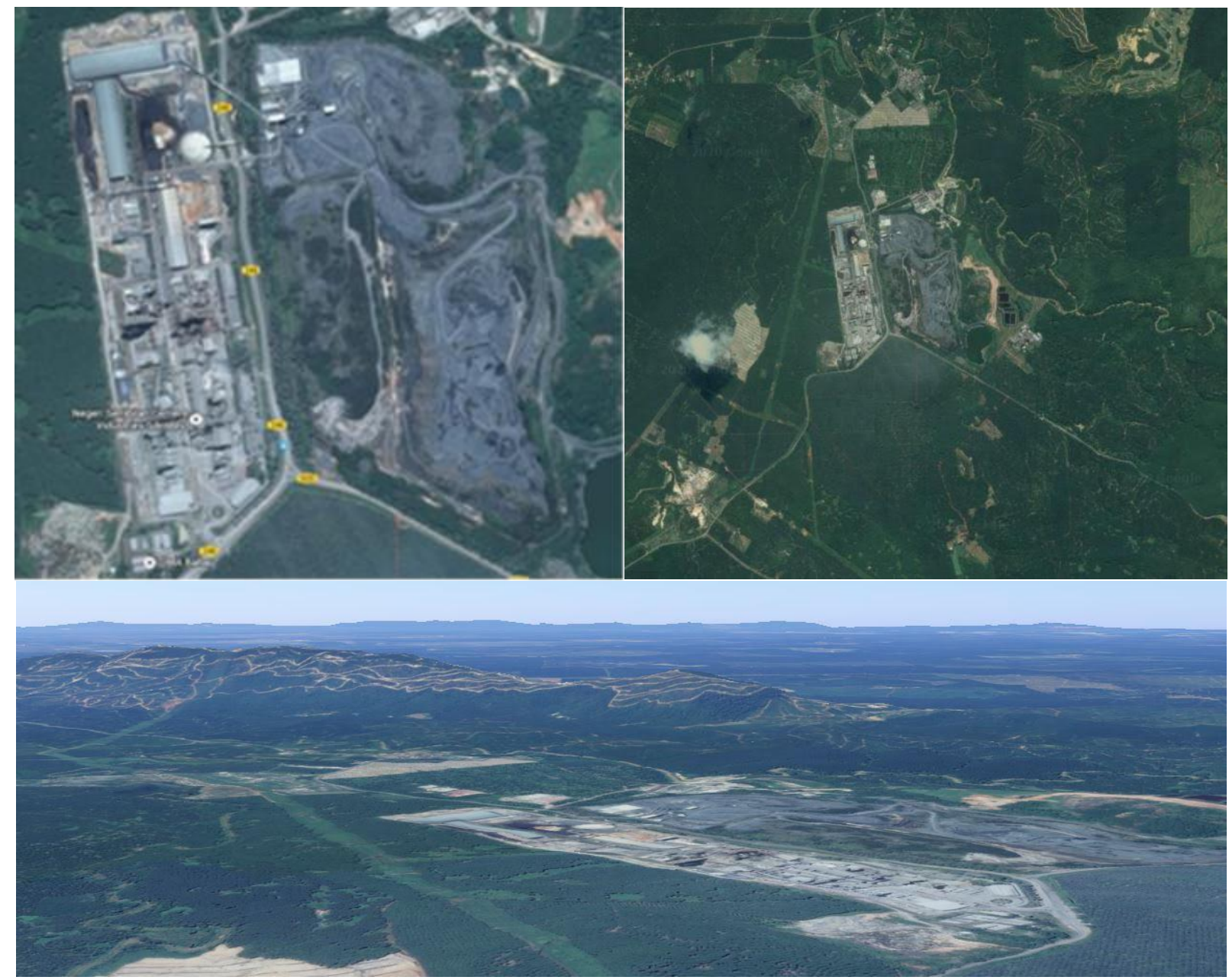

Fig. 1. Cement industrial plant located opposite to quarrying plant.

\section{Study Sample}

A total of 123 workers were selected by using simple random sampling. The directly exposed group was comprised of those who are exposed to respirable cement dust more than or equal to three hours a day while working in the production line in the cement industry. Meanwhile, the comparative group was comprised of those who are indirectly exposed to respirable cement dust less than three hours a day and most of the time work in a closed office at the cement industry. The name lists of both groups of the study were obtained from the human resource department of the cement industry. All the department processes were involved in this study from the quarrying process, raw mills, cement mills, packaging, transporting (in-house), managing and cleaning. The inclusion criteria in this study were Malaysian male workers, age range 24 to 55 years old, and working in this industry for six months or more, without any ongoing treatment for respiratory diseases during the sampling time. The medical treatment for lung disease or lung allergies, such as corticosteroids, $\beta 2$-agonists, leukotriene modifiers and Hi-antagonists, at least six weeks prior to the test because it will reduce their inflammation and relief the pulmonary which can affect the accuracy of sampling data (Barnes, 2006). The exposure to $\mathrm{Si}, \mathrm{As}$ and $\mathrm{Cr}$-contained breathable dust from cement while working in the cement industry needs at least six months or more to show the asthmatic symptoms for longterm exposure (Tarlo et al., 2010). Therefore, the respondent who have received a treatment or under medication during the sampling will be excluded, however their sample will be obtain after six months prior of the medication intake. The research proposal was reviewed and the approval letter was approved by the Medical Ethics Committee of the Faculty of Medicine and Health Sciences Universiti Putra Malaysia to conduct a research study on cement industrial workers (FPSK: EXP16 P12/6).

\section{Instruments and Procedures}

The self-administrated questionnaire for workers is adopted from the American Thoracic Society for Respiratory Disease ATS-DLD questionnaire used for adults in epidemiology research (Ferris, 1978). A pilot study is a pretest of a questionnaire conducted randomly on 50 workers in other dusty industrial dual-language Malay and English to determine their understanding of the questionnaire and to measure the timeframe for them to finish answering all the questions. The validation by the expertise of the linguistic faculty to ensure the dual-language questionnaire was in the same sense by translation method in dual-language Malay 
and English. The reliability of the questionnaire was analysed using the Alpha Reliability Coefficient statistical test to determine Cronbach's alpha $(\alpha)$ with a range of $0.83-0.95$ for all sections. The range value of the stability coefficient is between 0 and 1 , the value of which reaches almost 1 indicates excellent reliability.

Personal respirable dust exposure was collected by using an SKC Nylon Cyclone and air sampling pump (Gilian GilAir-3) with a $1.7 \mathrm{~L} \mathrm{~min}^{-1}$ air flow rate, placed at the breathing zone area for eight hours working duration. Polyvinyl chloride (PVC) filter papers were used in the mineral dust sampling, with a $0.8 \mu \mathrm{m}$ pore size and $37 \mathrm{~mm}$ diameter. First, the filter papers were dried in a furnace for eight hours at $100^{\circ} \mathrm{C}$ before they were wrapped with aluminum foil and labeled. After storage in a desiccator for 24 hours, the filter papers were weighed using a six-digit electronic microbalance (Sartorius CPA2P). The acid digestion method was performed to extract cement mineral dust from the filter papers, which was analyzed using inductively coupled plasma-mass spectrometry (ICP-MS) to determine the concentration of As and $\mathrm{Cr}$. The extraction method was performed by following the National Institute of Occupational Safety and Health (NIOSH) Manual of Analytical Method 7300 for elements by ICP (Milson et al., 2003; Latif et al., 2011; Rodriguez-Cotto et al., 2014). Meanwhile, the procedure for Si respirable dust exposure was performed following the NIOSH Manual of Analytical Method 7500 using X-ray powder diffraction (XRD) analysis (Key-Schwartz et al., 2003). The Si samples were filtered onto the silver filter, and the integrated diffraction intensity of Si powder deposited was X-rayed.

The standard reference material (SRM) for quartz Si used for calibration standard concentrations is code 461 of the Japan Association for Working Environment Measurement (JAWE). It is $99.32 \%$ purity of quartz $\mathrm{Si}$ with a particle concentration of less than $10 \mu \mathrm{m}$ through a respirable fraction. Six levels of standard quartz Si calibration were deposited on a filter calibration set with concentrations of $10,20,50,100,250$ and $500 \mu \mathrm{g} \mathrm{mL}^{-1}$. The preparation of the standard solution followed the NIOSH Manual of Analytical Methods 7500 (NMAM 7500) for Si Crystalline using XRD analysis (Key-Schwartz et al., 2003). The increase of 2.7721 times the Si weight $(\mu \mathrm{g})$ plus the constant value of 0.075 will increase the integrated intensity of X-ray diffraction spectrometry (XRD) as shown in calibration curve Fig. 2. The standard reference material (SRM) solution for tracing As and $\mathrm{Cr}$ element concentration using Inductively Coupled Plasma-Mass Spectrometry (ICP-MS) was Perkin Elmer multi-element calibration standard 3 for ICP with $10 \mu \mathrm{g} \mathrm{mL}^{-1}$ $=10000 \mathrm{mg} \mathrm{m}^{-3}$ each concentration of 29 elements in $5 \%$ nitric acid $\left(\mathrm{HNO}_{3}\right)$. The wavelength of the element As is $189 \mathrm{~nm}$ and the element $\mathrm{Cr}$ is $267 \mathrm{~nm}$. The As linear equation $y=1457.7 x+1333$ shows that for each increasing of 1457.7 times of As concentration $\left(\mathrm{mg} \mathrm{m}^{-3}\right)$ and plus 1333 as a constant value will increase the spectrophotometry intensity. Meanwhile, an increase of 6356.4 times the concentration of $\mathrm{Cr}\left(\mathrm{mg} \mathrm{m}^{-3}\right)$ plus a constant value of 94496 increases the intensity of spectrophotometry with linear equation $\mathrm{y}=$ $6356.4 x+94496$.
The respondent weight was measured by using Tanita HD-319 series digital personal weight scale manufactured from Japan. The scale was calibrated for eccentricity test to ensure the load's center of gravity is in the highest range. Then, the scale was tested for repeatability issues and weighing test for the accuracy. Seca 206 model for roll-up measuring tape was used to measure the height of the respondent.

In this study, Spirometry System ChestGraph HI-105 model was used on the workers for lung function test. According to the manual instruction of Chest Spirometry ChestGraph HI105 model system is a non-calibration sensor with $\pm 3 \%$ or within $\pm 50 \mathrm{~mL}$ volume accuracy according to ATS Standard. Before each measurement session, the disposable mouthpiece was changed and the patient used a rubber glove without touching the new mouthpiece in the sanitising package to be installed. The mouthpiece was placed in the lips of the subject and asked them to close completely, ensuring that the position of the mouthpiece was sealed around the lips. The subject needs to inhale deeply and thoroughly through the mouthpiece, as far as possible, until the lungs are filled to the maximum. Then, the subject needs to exhale with the maximum force in the breathing tube until no more air is released. The result was generated immediately after the test and analysed using an analytical method. All electronic instruments used in this study were calibrated before and after the standard procedure was established

Exhaled Nitric Oxide is determined using the NIOX MINO device to indicate the level of inflammation of the airway using the Aerocrine electrochemical sensor technology. NIOX MINO instruments are used as medical devices and are regulated by the US Food and Drug Administration in the United States. The NIOX device is maintenance-free and calibrated, and the quality value is guaranteed by Aerocrine. This is a handheld instrument for exhaled nitric oxide (NO) analysis measurement range 5-300 ppb below 2 minutes. The workers were guided on how to use NIOX MINO Airway Inflammation Monitor to measure the concentration of FENO in human exhaled breathing. Before each measuring session, the disposable patient filter and the patient must be removed using each plastic filter cover without contacting the filter. The principle that NIOX Mino operates by ensuring that the instrument is ready for measurement and that the subject needs to empty the lungs first by exhalation before inhalation through the mouthpiece of the NIOX filter at total lung capacity. They were ensured that there was no free air at total lung capacity to trigger the measurement procedure. Continuous sound is heard, and a steady top light is shown, indicating that the inhalation pressure is maintained. Slowly, the subject needs to exhale through the filter until the top light and the sound are switched off. Standard exhalation sampling has been performed for 10 seconds, which means that the Nitric Oxide level is flow-dependent and the exhalation rate for a valid measurement is within $50 \pm 5 \mathrm{~mL} \mathrm{~s}^{-1}$.

\section{Data Analysis}

The data of cement mineral dust containing $\mathrm{Si}, \mathrm{As}$, and $\mathrm{Cr}$ were analyzed by using SPSS version 22 software to compare the mean concentrations between manufacturing and administrative workers. The data were then used to 

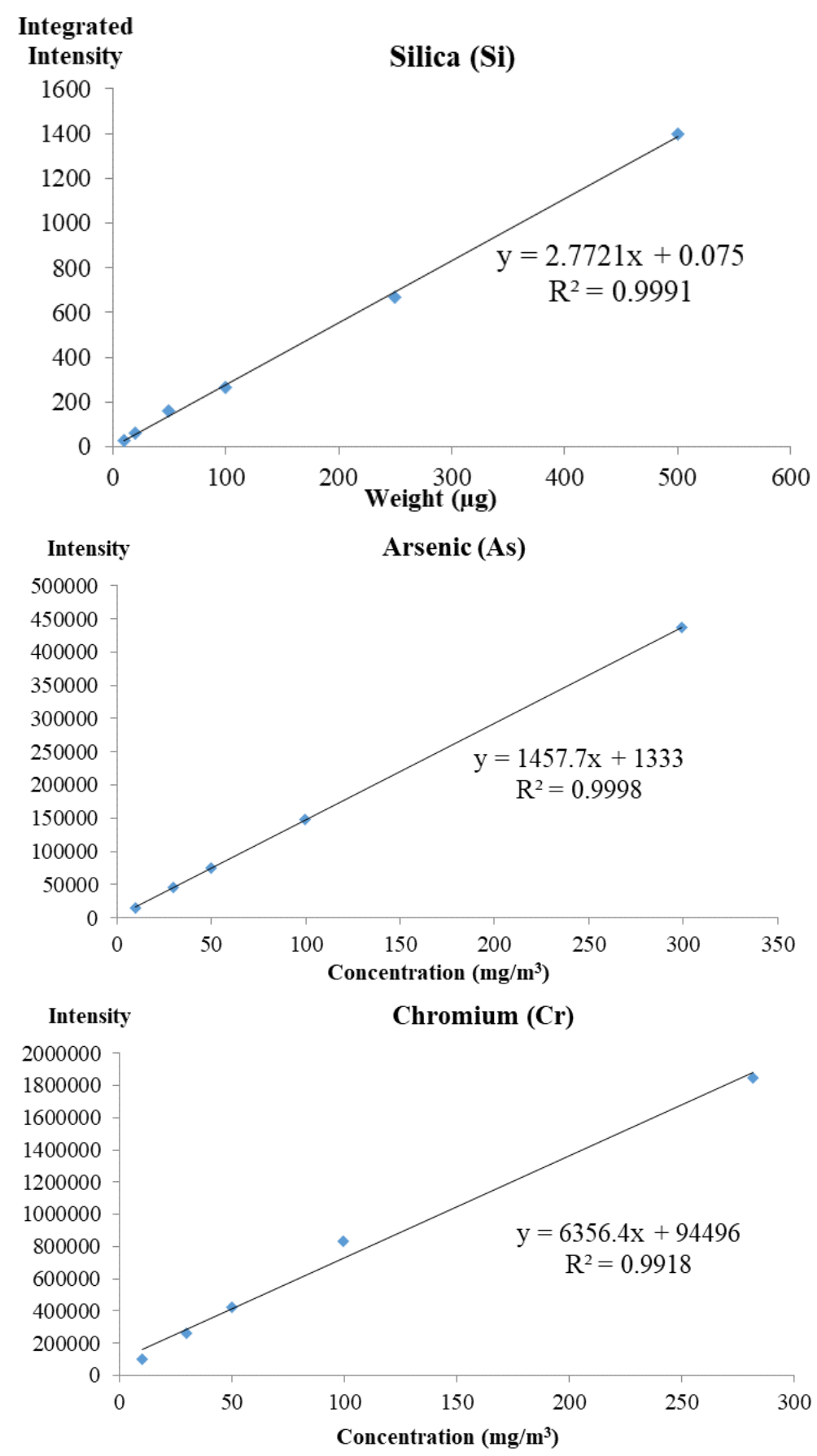

Fig. 2. Calibration curve for $\mathrm{Si}$, As and $\mathrm{Cr}$ standard solution.

determine the respiratory health risk assessment for cancer risk and non-cancer risk probability. The probability of cancer risk effect due to exposure to respirable $\mathrm{Si}, \mathrm{As}$, and $\mathrm{Cr}$ dust in the cement industry was calculated using the equation from U.S. EPA (1989) for the ILCR. HQ assessment was adopted from U.S. EPA (1989) to determine the non-cancer risk health effect due to respirable $\mathrm{Si}, \mathrm{As}$, and $\mathrm{Cr}$ dust exposure.

$I L C R=\frac{(C \times B R \times D S \times E F \times E D)}{(B W \times A T)} \times C S F$
$H Q=C \times D S \times E F \times\left(11.4 \times 10^{-4}\right) \mathrm{hr} \operatorname{yerar}^{-1} \times \frac{1}{R E L}$

where ILCR = incremental lifetime cancer risk, $\mathrm{HQ}=$ hazard quotient, $\mathrm{C}=$ exposure concentration in air $\left(\mathrm{mg} \mathrm{m}^{-3}\right), \mathrm{BR}=$ breathing rate $\left(\mathrm{m}^{3} \mathrm{hr}^{-1}\right), \mathrm{DS}=$ daily shift $\left(\mathrm{hr}\right.$ day $\left.^{-1}\right), \mathrm{EF}=$ exposure frequency (day year ${ }^{-1}$ ), ED $=$ exposure duration (years), $\mathrm{BW}=$ bodyweight $(\mathrm{kg}), \mathrm{AT}=$ averaging time for cancer effects (equals to the life expectancy in days), CSF = cancer slope factors $\left(\mathrm{mg} \mathrm{kg}^{-1} \mathrm{~d}^{-1}\right)$, and REL $=$ chronic reference exposure level $\left(\mathrm{mg} \mathrm{m}^{-3}\right)$. 
The intensity of physical activities contributes to the distinctive breathing rates of workers. According to Stifelman (2007), male adults have high breathing rate values as compared to female adults. Therefore, the U.S. EPA has summarized the breathing rates of each gender according to activities level: light, moderate, and heavy as in Fig. 3 (U.S. EPA, 2015). Light intensity activities refer to passive indoor works with less physical energy use such as office work, supervision, light cleaning, minor repairment, wheelbarrow push $(<15 \mathrm{~kg}$ load), or bricks stacking. Moderate activities refer to active tasks of high energy consumption such as climbing, carrying loads, heavy lifting, welding, repairing, heavy cleaning, long-distance walking, or wheelbarrow pushing ( $\geq 15 \mathrm{~kg}$ load). Meanwhile, heavy work activities allude to vigorous physical activities or two or more moderate activities at once such as construction work, climbing while heavy- lifting, drilling, long-distance running, cycling or chopping with an axe.

Exposure duration of workers refers to the average years of work in a company under the same pollutant exposure. The average tenure of workers is 20 years with continuous service under the same employer (U.S. EPA, 2011). The average time for developing cancer effects equals to 70 years life expectancy (U.S. EPA, 2011). The Malaysian working days in a yearly basis is known as the worker's exposure frequency prescribed under the Employment Act 1955 (Act 265). The normal working hour for every employee is eight hours per day and 48 hours per week. The maximum working days for administrative workers for this study were 250 days annually. However, for the massive production industries which operated 24 hours daily, the maximum working days for manufacturing workers are 302 days with one-off- day weekly.

The cancer slope factor (CSF) is a 95\% confidence level of IARC on the expectation of the lifetime cancer risk due to hazardous exposure. CSF may also be derived from the inhalation unit risk value (U.S. EPA, 1989). Currently, no CSF for Si had been included in the integrated risk information system (IRIS) for chemical assessment. However, Goldsmith et al. (1995) recommended that the lifetime CSF for Si health risk is between $3.09 \times 10^{-4}-116.00 \times 10^{-4} \mathrm{mg} \mathrm{kg}^{-1} \mathrm{~d}^{-1}$, and most likely is $84.30 \times 10^{-4} \mathrm{mg} \mathrm{kg}^{-1} \mathrm{~d}^{-1}$. While reference exposure level (REL) agreed by the American Conference of Government Industrial Hygienist (ACGIH) is $0.003 \mathrm{mg} \mathrm{m}^{-3}$. U.S. EPA recommends the CSF and REL for As, and Cr (VI) showed in Table 1.

The calculation of health risk assessment for the occupational sector was considered the prevention and control measure implemented in the working area as an alternative to reduce the exposure effect of cancerous and non-cancerous diseases among workers. The Malaysia Occupational Safety and Health Act 1994 (Act 514) under Part IV in Section 15 prescribes the general duties of employers and self-employed persons to provide safety, health, and welfare to employees in their working area (Malaysia, 2011). Therefore, dusty industrial are urged to execute prevention and control measures to reduce workers exposure.

An N95 mask or full-face respirator was found to have 90\%-95\% effectiveness in reducing respirable dust exposure (Lahiri et al., 2005). The implementation of engineering control, a ventilation system, or a dust control system may reduce the exposure by 65-86\% (Cecala et al., 2000; Lahiri et al., 2005; Yeheyis et al., 2012). Working behavior also can contribute in reducing the risk of dust exposure by 20 $50 \%$ and $58 \%$ by attending occupational safety and health (OSH) training and blowing clothes after entering the dusty working area, respectively (Cecala and Thimons, 1993; Lahiri et al., 2005). Thus, the ILCR and HQ calculations were reformulated by considering the implementation of prevention and control measures to reduce the risk of respirable dust exposure (Yeheyis et al., 2012). The number of factor reductions may vary according to the prevention and control measures that have been implemented in the industry.

$\mathrm{ILCR}_{\mathrm{pc}}=\mathrm{ILCR} \times\left(1-\mathrm{RPC}_{1}\right) \times\left(1-\mathrm{RPC}_{2}\right) \times\left(1-\mathrm{RPC}_{\mathrm{n}}\right)$

$\mathrm{HQ}_{\mathrm{pc}}=\mathrm{HQ} \times\left(1-\mathrm{RPC}_{1}\right) \times\left(1-\mathrm{RPC}_{2}\right) \times\left(1-\mathrm{RPC}_{\mathrm{n}}\right)$

where, $\mathrm{ILCR}_{\mathrm{pc}}=$ incremental lifetime cancer risk with prevention and control measures, ILCR = incremental lifetime cancer risk, $\mathrm{HQ}_{\mathrm{pc}}=$ hazard quotient with prevention and

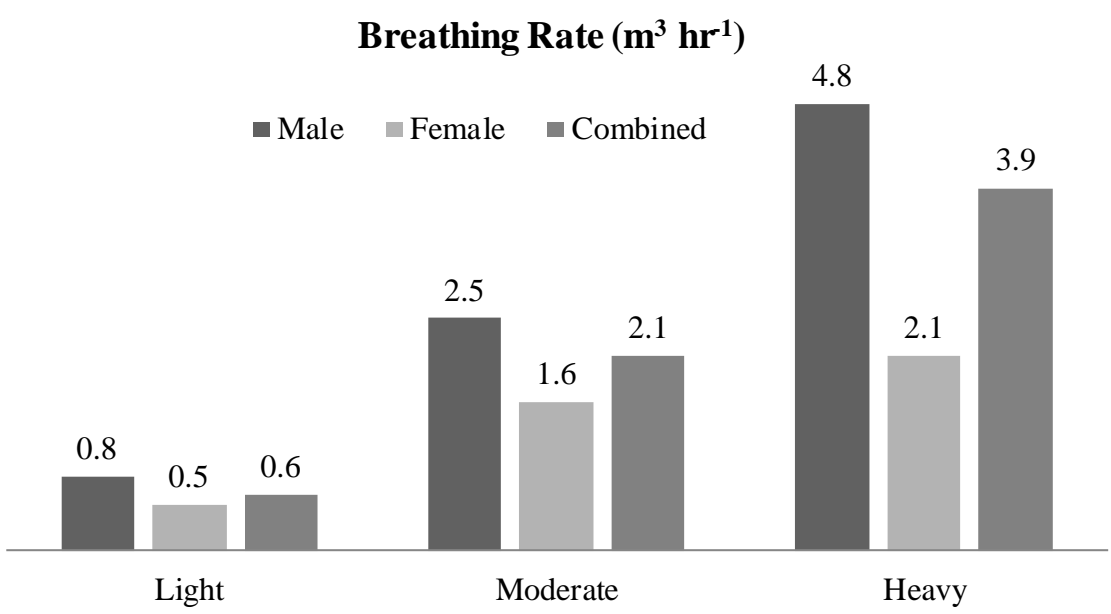

Fig. 3. Breathing rate according to physical activities (U.S. EPA, 2015). 
Table 1. Input parameter and reference value for respiratory health risk assessment.

\begin{tabular}{|c|c|c|}
\hline Input parameter & Distribution values & Source \\
\hline Exposure concentration in air, $\mathrm{C}\left(\mathrm{mg} \mathrm{m}^{-3}\right)$ & - & Data calculated \\
\hline \multicolumn{3}{|l|}{ Breathing rate, $\mathrm{BR}\left(\mathrm{m}^{3} \mathrm{hr}^{-1}\right)$ : } \\
\hline -Light activities (administrative workers) & 0.8 & U.S. EPA (2011) \\
\hline -Moderate activities (manufacturing workers) & 2.5 & \\
\hline Daily shift, DS (hr day $\left.{ }^{-1}\right)$ & 8 & $\begin{array}{l}\text { U.S. EPA (2011), Employment } \\
\text { Act 1955, (Act 265) }\end{array}$ \\
\hline \multicolumn{3}{|l|}{ Exposure frequency, EF (day year ${ }^{-1}$ ) } \\
\hline -Administrative workers & 250 & Employment Act 1955, (Act 265) \\
\hline -Manufacturing workers & 302 & \\
\hline Exposure duration, ED (years) & 20 & U.S. EPA (2011) \\
\hline $\begin{array}{l}\text { Averaging time for cancer effects (equals to the life } \\
\text { expectancy in years), AT (days) }\end{array}$ & $\begin{array}{l}70 \text { years } \times 365 \text { day year }{ }^{-1} \\
=25550\end{array}$ & U.S. EPA (2011) \\
\hline Bodyweight, BW (kg) & - & Data calculated \\
\hline \multicolumn{3}{|l|}{ Cancer slope factors, $\mathrm{SF}\left(\mathrm{mg} \mathrm{kg}^{-1} \mathrm{~d}^{-1}\right)$} \\
\hline$-\mathrm{Si}$ & $8.43 \times 10^{-3}$ & Goldsmith et al. (1995) \\
\hline -As & $1.51 \times 10^{1}$ & U.S. EPA (1995) \\
\hline$-\mathrm{Cr}(\mathrm{VI})$ & $4.1 \times 10^{1}$ & U.S. EPA (1998) \\
\hline \multicolumn{3}{|l|}{ Chronic reference exposure level, REL $\left(\mathrm{mg} \mathrm{m}^{-3}\right)$} \\
\hline$-\mathrm{Si}$ & 0.003 & ACGIH (2005) \\
\hline -As & 0.0002 & U.S. EPA (1995) \\
\hline$-\mathrm{Cr}(\mathrm{VI})$ & 0.0001 & U.S. EPA (1998) \\
\hline
\end{tabular}

control measures, $\mathrm{HQ}=$ hazard quotient, and $\mathrm{RPC}=$ reduction of prevention and control measures. A detailed description of the input parameters and the distribution values used in the calculation of the ILCR and HQ is presented in Table 2.

$\mathrm{Cr}$ is essential to the human body in a small amount, and $\mathrm{Cr}$ (III) exists naturally in rocks and soil. The results generated by ICP-MS were total mixed of both trivalent chromium (Cr III) and hexavalent chromium ( $\mathrm{Cr}$ (VI)). $\mathrm{Cr}$ (VI) is reported as a class 1 carcinogen, while $\mathrm{Cr}$ (III) has no sufficient evidence regarding carcinogenicity. Moreover, studies directly focusing on exposure to $\mathrm{Cr}$ (III) alone are not available. Nevertheless, $\mathrm{Cr}$ (III) is easily transformed into $\mathrm{Cr}$ (VI) through the oxidation process in cement production (Frias et al., 1994; Klemm, 1994; Bae et al., 2017). Thus, it is assumed that the worst-case exposure to cement dust is from $\mathrm{Cr}(\mathrm{VI})$.

The minimum acceptable lifetime cancer risk set by the Environment Protective Agency (EPA) and the World Health Organization's (WHO) for IARC is less than 1 in 1 million $\left(0.01 \times 10^{-4}\right)$ (U.S. EPA, 2012). However, this minimally acceptable level is not suitable in an occupational setting, where workers are highly exposed to hazardous material for an eight- hour working day. Besides, several industries have implemented prevention and control measures to reduce the risk of exposure. Therefore, the NIOSH has considered control technologies, exposure assessment, and management system implementation, and it recommends a minimum level of lifetime cancer risk exposure among workers of 1 in 10,000 cases $\left(1 \times 10^{-4}\right)$ (Whittaker et al., 2017).

However, there is no acceptable HQ limit in an industrial district that has been recommended by the NIOSH or the Occupational Safety and Health Administration (OSHA). Thus, HQ values less than or equal to 1 can be considered to have negligible hazard or the least adverse effects according to the EPA and the IARC (U.S. EPA, 2015; IARC, 2019).

\section{RESULTS AND DISCUSSION}

\section{Anthropometric Measurement and Age}

The study comprised male cement workers who have been working in this industry for six months or more. The anthropometric measurement and age of the respondents showed in Table 3 had no significant difference between the study groups $(p>0.05)$. The mean age of the manufacturing workers was 36.46 years, with a standard deviation of 8.14 years. Meanwhile, the administrative workers were $38.82 \pm$ 8.39 years. The weight and height of the manufacturing and administrative workers were $79.01 \pm 13.28 \mathrm{~kg}$ and $168.52 \pm$ $6.00 \mathrm{~cm}$ and $77.71 \pm 12.89 \mathrm{~kg}$ and $167.69 \pm 6.19 \mathrm{~cm}$, respectively. The smoking status and working tenure were controlled, and no significant differences were found among the respondents. It was determined that $47.2 \%$ and $52.9 \%$ of the manufacturing and administrative workers, respectively, were smokers. The cement industry was dominant with tenure less than or equal to 10 years of working, $58.3 \%$ in the manufacturing department and $49.0 \%$ as administrative workers.

\section{Socio-demographic Factors}

From the statistical analysis, it was found that there was no significant difference in current tenure among the respondent groups $\left(\chi^{2}=2.705, \mathrm{p}=0.259\right)$. Most of the respondents had worked for less than or equal to 10 years with $58.1 \%$ of the manufacturing group and $47.3 \%$ of the administrative group. Cement industrial manufacturing and administrative workers accounted for $73.3 \%$ and $78.4 \%$ of had previous employment in no dusty industry. The majority of the workers in the cement industry were Malay where there were $90.5 \%$ of 
Table 2. Percentage of exposure reduction.

\begin{tabular}{lll}
\hline Prevention and Control Measures & Exposure Reduction $(\%)$ & Source \\
\hline Engineering control & $70-86 \%$ & Lahiri et al. $(2005)$ \\
& $65 \%$ & Yeheyis et al. $(2012)$ \\
Ventilation system & $69 \%$ & Cecala et al. $(2000)$ \\
& $70-85 \%$ & Lahiri et al. $(2005)$ \\
Wet method & $89 \%$ & NIOSH (1998) \\
Dust control system & $76 \%$ & Cecala et al. $(2000)$ \\
Blowing clothes & $58 \%$ & Cecala and Thimons $(1993)$ \\
OSH Training & $20-50 \%$ & Lahiri et al. $(2005)$ \\
Respirator & & \\
$\quad$-Full face & $95 \%$ & Lahiri et al. $(2005)$ \\
$\quad$-half face & $90 \%$ & \\
Mask & & \\
$\quad$-with filter dust & $80 \%$ & Lahiri et al. $(2005)$ \\
$\quad$-comfort mask/clinical mask & $30 \%$ & Yeheyis et al. $(2012)$ \\
Personal Protective Equipment (PPE) & $78 \%$ & \\
\hline
\end{tabular}

Table 3. Comparison of anthropometric measurement and age between manufacturing and administrative workers.

\begin{tabular}{|c|c|c|c|c|}
\hline \multirow{2}{*}{ Variables } & Manufacturing $(\mathrm{n}=72)$ & Administrative $(\mathrm{n}=51)$ & \multirow{2}{*}{$T$-value } & \multirow{2}{*}{$p$-value } \\
\hline & Mean \pm SD & Mean \pm SD & & \\
\hline Age (years) & $36.46 \pm 8.14$ & $38.82 \pm 8.39$ & -1.567 & 0.120 \\
\hline Weight (kg) & $79.01 \pm 13.28$ & $77.71 \pm 12.89$ & 0.544 & 0.587 \\
\hline Height (cm) & $168.52 \pm 6.00$ & $167.69 \pm 6.19$ & 0.743 & 0.459 \\
\hline
\end{tabular}

Independent Sample T-Test.

* Significant at $p<0.05$.

cement workers, 162 workers in the manufacturing group and 160 workers in the administrative group were Malay. This shows that there was no significant difference in races among the cement industry. Most cement industrial workers had SPM at the highest level of education, with $52.4 \%$ in the manufacturing group and $54.1 \%$ in the administrative group.

Respiratory health history information to indicate whether the history of family respiratory health or allergy has contributed to the respiratory health of workers. However, most of the respondents did not have a family respiratory disease. The percentage of the manufacturing group that did not have a family history of respiratory diseases was $75.2 \%$. In the meantime, the administrative group that did not have a family history of respiratory diseases was $79.7 \%$.

Smoking is one of the major confounders of respiratory disease studies. However, due to the large cement community represented by smokers, this study cannot exclude these respondents. The same number of smokers and non-smokers was therefore sought in the selection of respondents to reduce these factors as a confounder. There was therefore no significant difference in smoking status among the cement industrial workers $\left(\chi^{2}=5.621, \mathrm{p}=0.123\right)$. They were categorised into three groups: heavy smoker who smokes more than 20 pieces per day, moderate smoker who smokes between 10 and 20 pieces per day, and light smoker who smokes less than 10 pieces per day. These categories have been adopted by the Ministry of Health Malaysia smoking categories. Most of them were moderate smokers with $34.3 \%$ and $28.4 \%$ of smokers in the manufacturing and administrative respectively.

\section{Working Behavior}

Working behavior factors were essential to ensure that the prevention and control measures set up by the company are adequately protected and to prevent the risk of exposure among workers. Table 4 shows the comparison of working behavior between manufacturing and administrative workers. The variable "notice respiratory health risk" was indicated to determine whether the workers were aware and had respiratory health-consciousness of their exposure to dust. The majority of the cement workers realized that they were at high risk of respiratory diseases, with $84.7 \%$ in the manufacturing group and $90.2 \%$ in the administrative group.

Manufacturing workers in this study were interpreted as workers directly exposed to highly dusty cement flour for more than three hours a day in a plant. Most of them were provided with an N95 mask and respirator while working. The full-face respirator with dual filter cartilage were provided to manufacturing workers during emergency situation when the workers need to manually handle the cement mixture. However, $94.4 \%$ of them wore an N95 mask or respirator while working, and $5.6 \%$ admitted to not wearing the N95 mask or respirator for various reasons. Meanwhile, none of the administrative workers in the cement industry wore any mask or respirator because they were working in the office of the cement industry. There is no enforcement regarding wearing suitable PPE in this industry among administrative workers, since they are not directly exposed to cement mineral dust. Hence, there was a significant difference in the study group regarding wearing a mask or respirator while working $\left(\chi^{2}=107.718, p=<0.001\right)$. 
Table 4. Comparison of smoking status, tenure and working behavior between manufacturing and administrative workers.

\begin{tabular}{|c|c|c|c|c|}
\hline \multirow{2}{*}{ Variables } & Manufacturing $(\mathrm{n}=72)$ & Administrative $(\mathrm{n}=51)$ & \multirow{2}{*}{$\chi^{2}$} & \multirow{2}{*}{$p$-value } \\
\hline & Number $(\%)$ & Number $(\%)$ & & \\
\hline \multicolumn{5}{|c|}{ Smoking Status } \\
\hline Yes & $34(47.2)$ & $27(52.9)$ & 0.391 & 0.532 \\
\hline No & $38(52.8)$ & $24(47.1)$ & & \\
\hline \multicolumn{5}{|c|}{ Tenure (years) } \\
\hline$\leq 10$ & $42(58.3)$ & $25(49.0)$ & 1.087 & 0.581 \\
\hline $11-20$ & $20(27.8)$ & $18(35.3)$ & & \\
\hline$>20$ & $10(13.9)$ & $8(15.7)$ & & \\
\hline \multicolumn{5}{|c|}{ Notice respiratory health risk } \\
\hline Yes & $61(84.7)$ & $46(90.2)$ & 0.790 & 0.374 \\
\hline No & $11(15.3)$ & $5(9.8)$ & & \\
\hline \multicolumn{5}{|l|}{ Wear mask } \\
\hline Yes & $68(94.4)$ & $0(0.0)$ & 107.718 & $<0.001 *$ \\
\hline No & $4(5.6)$ & $51(100.0)$ & & \\
\hline \multicolumn{5}{|c|}{ Attend training } \\
\hline Yes & $30(41.7)$ & $16(31.4)$ & 1.351 & 0.245 \\
\hline No & $42(58.3)$ & $35(68.6)$ & & \\
\hline \multicolumn{5}{|c|}{ Clean clothes } \\
\hline Yes & $14(19.4)$ & $8(15.7)$ & 0.287 & 0.592 \\
\hline No & $58(80.0)$ & $43(84.3)$ & & \\
\hline \multicolumn{5}{|c|}{ Heavy duty work } \\
\hline Yes & $35(48.6)$ & $24(47.1)$ & 0.029 & 0.865 \\
\hline No & $37(51.4)$ & $27(52.9)$ & & \\
\hline
\end{tabular}

Chi-square test.

* Significant at $p<0.05$.

"Attend training" refers to the question "Are you attending any training on how to use a proper respirator or attending any course/seminar on respiratory health disease?" This question was asked to determine whether the workers had a basic knowledge of their respiratory health and how to wear suitable PPE. There was no significant difference among study respondents' claims that they did not attend or receive any training regarding respiratory disease or how to use an N95 mask and respirator (58.3\% of the manufacturing workers and $68.6 \%$ of the administrative workers).

Some dusty industries have set rules for cleaning clothes after working to ensure that the workers do not inhale the respirable dust trapped on their clothes after removing their mask or respirator. However, the cement industry has not implemented such rules among its workers, and only $19.4 \%$ and $15.7 \%$ of manufacturing and administrative workers, respectively, cleaned their clothes after working.

The heavy-duty work task and any physically stressful activities such as standing for an extended period, climbing, heavy lifting, running, walking a long-distance, working in a high- pressure or hot area, or using physical strength, contributed to workers' breathing rate. An increased breathing rate will increase the risk of inhalation exposure of the workers. The manufacturing group and the administrative group had $51.4 \%$ and $52.9 \%$ of respondents, respectively, who admitted not doing any heavy-duty work in their job. Thus, there was no significant difference between the manufacturing and administrative workers regarding heavyduty work in their job $\left(\chi^{2}=0.029, p=0.865\right)$.

\section{Respirable Cement Mineral Dust Exposure}

The main carcinogenic elements in cement dust are Si, As, and $\mathrm{Cr}$. The geometric mean and standard deviation of $\log$ $\mathrm{Si}$ concentrations in manufacturing workers were $5.27 \pm$ $2.36 \mathrm{mg} \mathrm{m}^{-3}$. Meanwhile, there were significantly lower log Si concentrations in the administrative worker group of $2.22 \pm$ $2.19 \mathrm{mg} \mathrm{m}^{-3}(F=5.696, p=<0.001)$. The highest concentration of Si determined in respirable cement dust was $21.82 \mathrm{mg} \mathrm{m}^{-3}$, and the lowest concentration was $0.26 \mathrm{mg} \mathrm{m}^{-3}$. The Malaysian Occupational Safety and Health Act 1994 (Act 514) and the Malaysian Factories and Machinery Act 1967 set the permissible exposure limit for exposure to crystalline $\mathrm{Si}$ (quartz) at $0.1 \mathrm{mg} \mathrm{m}^{-3}$ (Malaysia, 2011). Thus, all workers in the cement industry have been exposed to high respirable Si dust.

The Si dust exist in natural rock with less than $4.0 \mu \mathrm{m}$ of aerodynamic size is respirable by crusher operators at Malaysian quarries was found to exceed the permissible exposure limit by more than 30.5\% (Amran et al., 2017). The crusher operators are not directly exposed to the respirable Si dust, since they work inside a closed crane car. However, this is contradicted with the current study, where the workers were directly exposed to respirable $\mathrm{Si}$ in cement mineral dust. Besides, it was found that the workers had 1.57 times more likely of developing respiratory diseases and 1.94 times more likely of pneumoconiosis after annual exposure to $\mathrm{Si}$ dust higher than $2.0 \mathrm{mg} \mathrm{m}^{-3}$ (Attfield and Costello, 2004).

The permissible exposure limit for respirable As dust set in the Malaysia Occupational Safety and Health Act 1994 (Act 514) is $0.01 \mathrm{mg} \mathrm{m}^{-3}$ (Malaysia, 2011). However, the range 
of respirable As concentrations exceeded the limit by 0.03 $0.14 \mathrm{mg} \mathrm{m}^{-3}$ among cement workers. Manufacturing workers were found highly exposed to respirable cement mineral dust containing As at $0.10 \pm 0.02 \mathrm{mg} \mathrm{m}^{-3}$. Administrative workers were found to be slightly less exposed to respirable cement mineral dust containing As at $0.07 \pm 0.02 \mathrm{mg} \mathrm{m}^{-3}$. Workers in the Nigerian cement industry had higher As dust concentration exposure compared with the limit (Richard et al., 2016).

There was a significant difference in the exposure to respirable $\mathrm{Cr}$ mineral dust between the manufacturing group and the administrative group, as shown in Table $5(F=6.765$, $p=<0.001)$. The geometric mean of $\log \mathrm{Cr}$ concentrations was $1.53 \pm 2.47 \mathrm{mg} \mathrm{m}^{-3}$ in manufacturing workers and 0.55 $\pm 1.97 \mathrm{mg} \mathrm{m}^{-3}$ in administrative workers. The highest concentration of $\mathrm{Cr}$ dust exposure in respirable cement dust is $11.05 \mathrm{mg} \mathrm{m}^{-3}$, and the lowest concentration is $0.17 \mathrm{mg} \mathrm{m}^{-3}$. If these ranges were compared with the permissible exposure limit for $\mathrm{Cr}$ metal or $\mathrm{Cr}$ (III) in Act 514, 77.3\% of the cement workers exceeded $0.5 \mathrm{mg} \mathrm{m}^{-3}$ (Malaysia, 2011). Meanwhile, if those respirable dust were considered as the worst case of exposure to $\mathrm{Cr}$ (VI), all the cement workers exceeded $0.01 \mathrm{mg} \mathrm{m}^{-3}$.

The maximum $\mathrm{Cr}$ dust concentrations found in Portland cement composition were $425 \mathrm{mg} \mathrm{m}^{-3}$, with a range between $42 \mathrm{mg} \mathrm{m}^{-3}$ and $212 \mathrm{mg} \mathrm{m}^{-3}$ (Dietz et al., 2003). In contrast, Cr dust concentration was found to be lower in cement dust, with a mean concentration of $0.3 \mathrm{mg} \mathrm{m}^{-3}$ (Richard et al., 2016). The justification for this low level of exposure was effective engineering control measures.

\section{Respiratory Health Symptoms}

Four types of respiratory symptoms identified in this study were cough, phlegm, wheezing, and chest tightness. The respiratory symptoms showed significant difference among the manufacturing group, the administrative group, and the comparative group with cough $\left(\chi^{2}=14.576, \mathrm{p}=<0.001\right)$, phlegm $\left(\chi^{2}=26.868, \mathrm{p}=<0.001\right)$, wheezing $\left(\chi^{2}=8.555\right.$, $\mathrm{p}$ $=0.014)$ and chest tightness $\left(\chi^{2}=6.292, \mathrm{p}=0.043\right)$. Manufacturing workers had the higher symptom of cough with $24.8 \%$ of the group compared with administrative workers with $16.2 \%$. The number of respondents who claimed that they had phlegm in the manufacturing group was 36 workers and the administrative group was 18 workers. Manufacturing group had $14.3 \%$ of the respondents who was having chest wheezing on breathing, while for the administrative was $14.9 \%$. Cement industrial workers accounted for $12.4 \%$ and $13.5 \%$ of the manufacturing and administrative groups with chest tightness.
Cough was reported to have been $30 \%$ of exposure workers in the cement industry and $25.4 \%$ had phlegm and $7.5 \%$ had wheezing (Al-Neaimi et al., 2001). However, cement workers were highly reported to have phlegm and followed by cough in this study. Aminian et al. (2014) found that cement production workers had significantly higher respiratory symptoms with $11 \%$ cough compared to office cement workers. This study reported less chest tightness among cement workers compared to another study in Malaysia that reported $19.4 \%$ of exposed workers in the cement industry had chest tightness (Noor et al., 2000). A study reported a high prevalence of respiratory symptoms from cement exposure with $37.5 \%$ of respiratory signs and symptoms such as cough and wheezing (Manjula et al., 2013). Respondents who were exposed to cement dust were found to have a prevalence of cough and wheezing of 96\% (Mehraj et al., 2013). Previous study reported various respiratory health symptoms among manufacturing workers compared to administrative workers due to highly exposed to dust. The administrative workers was found having a symptoms of chest wheezing and chest tightness due to indirectly exposed with the respirable cement dust that trapped in the office building.

\section{Lung Function}

The mean $\mathrm{FVC}$ and $\mathrm{FEV}_{1}$ manufacturing group were $3.08 \pm$ $0.59 \mathrm{~L} \mathrm{~s}^{-1}$ and $2.76 \pm 0.52 \mathrm{~L} \mathrm{~s}^{-1}$ while in administrative group were $2.84 \pm 0.55 \mathrm{~L} \mathrm{~s}^{-1}$ and $2.54 \pm 0.50 \mathrm{~L} \mathrm{~s}^{-1}$. The mean of ratio $\mathrm{FEV}_{1} / \mathrm{FVC}$ among the manufacturing and administrative groups were $0.90 \pm 0.05 \mathrm{~L} \mathrm{~s}^{-1}, 0.90 \pm 0.06 \mathrm{~L} \mathrm{~s}^{-1}$ respectively. The mean $\mathrm{FVC} \%$ predicted in the manufacturing group was $89.51 \pm 14.27$ and the administrative group was $85.91 \pm 13.03$. The administrative group had the lowest $\mathrm{FEV}_{1} \%$ predicted mean at $87.95 \pm 13.72$, compared to the manufacturing group at $91.34 \pm 15.80$. Cement industry workers predicted a mean $\mathrm{FEV}_{1} / \mathrm{FVC} \%$ of $102.27 \pm 6.09$, with $102.10 \pm 5.92$ in the manufacturing group and $102.51 \pm 6.36$ in the administrative group.

The manufacturing group had $23.8 \%$ abnormalities in FVC\% predicted and $18.1 \%$ abnormalities in $\mathrm{FEV}_{1} \%$ predicted. Administrative group had $29.7 \%$ abnormalities in FVC $\%$ predicted and $28.4 \%$ abnormalities in $\mathrm{FEV}_{1} \%$ predicted. The total percentage of cement workers who had FVC\% predicted and $\mathrm{FEV}_{1} \%$ predicted abnormalities was $26.3 \%$ and $22.3 \%$ respectively. Lung function of cement production workers was found to be significantly associated with a decrease compared to administration workers (Nordby et al., 2011). All respondents were expected to have a normal $\mathrm{FEV}_{1} / \mathrm{FVC} \%$ predicted in this study. On the contrary, the study of cement industrial workers in the United Arab

Table 5. Comparison of respirable cement mineral dust exposure between manufacturing and administrative workers.

\begin{tabular}{|c|c|c|c|c|c|}
\hline \multirow{2}{*}{ Variable } & Manufacturing $(\mathrm{n}=72)$ & Administrative $(\mathrm{n}=51)$ & \multirow{2}{*}{ range } & \multirow{2}{*}{$T$-value } & \multirow{2}{*}{$p$-value } \\
\hline & $\mathrm{GM} \pm \mathrm{SD}$ & $\mathrm{GM} \pm \mathrm{SD}$ & & & \\
\hline $\log \mathrm{Si}\left(\mathrm{mg} \mathrm{m}^{-3}\right)$ & $5.27 \pm 2.36$ & $2.22 \pm 2.19$ & $0.26-21.82$ & 5.696 & $<0.001 *$ \\
\hline As $\left(\mathrm{mg} \mathrm{m}^{-3}\right)$ & $0.10 \pm 0.02$ & $0.07 \pm 0.02$ & $0.03-0.14$ & 6.835 & $<0.001 *$ \\
\hline $\log \mathrm{Cr}\left(\mathrm{mg} \mathrm{m}^{-3}\right)$ & $1.53 \pm 2.47$ & $0.55 \pm 1.97$ & $0.17-11.05$ & 6.765 & $<0.001 *$ \\
\hline
\end{tabular}

Independent Sample T-Test.

* Significant $p<0.05$. 
Emirates (UAE) found that $36 \%$ of exposed workers had $\mathrm{FEV}_{1} / \mathrm{FVC} \%$ predicted abnormalities for the lung function test compared to unexposed workers (Al-Neaimi et al., 2001). This was a difference from the finding in this study. However, Kim et al. (2015) was found that $21.6 \%$ of high exposure group had abnormalities of $\mathrm{FVC} \%$ predicted. The cement workers showed prevalence of $\mathrm{FVC} \%$ predicted and $\mathrm{FEV}_{1} \%$ predicted with $26.3 \%$ and $22.3 \%$ respectively similarly founded by Noor et al. (2000) and Al-Neaimi et al. (2001).

Although Si concentration was found to be the highest among manufacturing workers compared to administrative workers, the Pearson Correlation showed that Si exposure among administrative workers was significantly related to FVC $\%$ predicted and $\mathrm{FEV}_{1} \%$ predicted $(\mathrm{r}=0.399, \mathrm{p}=$ $0.004)$ and $(r=0.434, p=0.001)$ respectively. This means that increased exposure to $\mathrm{Si}$ respirable dust would increase the tendency of abnormalities of the FVC\% predicted and $\mathrm{FEV}_{1} \%$ predicted by administrative workers. Meanwhile, Si exposure to manufacturing workers had a significant weak relationship with $\mathrm{FVC} \%$ predicted $(\mathrm{r}=0.295, \mathrm{p}=0.008)$. The correlation of $\mathrm{Si}$ concentration with $\mathrm{FVC} \%$ predicted and $\mathrm{FEV}_{1} \%$ predicted among cement workers had a significant relationship with $(\mathrm{r}=0.259, \mathrm{p}=0.003)$ and $(\mathrm{r}=0.208, \mathrm{p}=$ $0.017)$ respectively.

As the concentration in the administrative and manufacturing air sample showed a significant correlation with FVC\% predicted $(\mathrm{r}=0.316, \mathrm{p}=0.006)$ and $(\mathrm{r}=0.316, \mathrm{p}=0.005)$ respectively. This means that the increasing exposure to As in administrative and manufacturing workers will increase the abnormalities status of FVC\% predicted of lung function. The $\mathrm{FEV}_{1} \%$ predicted of the manufacturing workers had a significant weak correlation with As dust concentration $(\mathrm{r}=$ $0.234, p=0.047$ ). However, As concentration in all cement workers showed a significant weak relationship on FVC\% predicted and $\mathrm{FEV}_{1} \%$ predicted status $(\mathrm{r}=0.239, \mathrm{p}=0.006)$ and $(\mathrm{r}=179, \mathrm{p}=0.041)$ respectively.

The administrative group showed a significant correlation between exposure to $\mathrm{Cr}$ respirable dust on lung function FVC\% predicted and $\mathrm{FEV}_{1} \%$ predicted status of with $(\mathrm{r}=$ $0.348, \mathrm{p}=0.007)$ and $(\mathrm{r}=0.334, \mathrm{p}=0.010)$ respectively. Besides, FVC\% predicted status showed a significant relationship with exposure to $\mathrm{Cr}$ respirable dust among manufacturing workers $(r=0.330, p=0.004)$ and a significant weak relationship among all cement workers $(r=0.236, p=$ 0.006). This means that administrative workers had higher abnormalities in their lung function with an increase in $\mathrm{Cr}$ in respirable dust compared to manufacturing workers

\section{Fractional Exhaled Nitric Oxide}

The geometric mean concentration of FENO in cement industrial workers was $30.02 \pm 26.55 \mathrm{ppb}$. Cement industrial workers, there was $31.76 \pm 27.29 \mathrm{ppb}$ geometric mean concentration of FENO in the manufacturing group and $28.28 \pm 26.24 \mathrm{ppb}$ geometric mean concentration of FENO in the administrative group. However, there is no significant difference in FENO concentration between these two cement industrial groups $(\mathrm{T}=-2.779, \mathrm{p}=0.067)$.

A study in cement factory workers on the effect of FENO in Tanzania showed no significant difference between the concentration of FENO among exposure workers with control groups (Tungu et al., 2013), and a decrease of $2 \mathrm{ppb}$ after shifting of work (Tungu et al., 2016). The possible reason for these studies to find a lower concentration of FENO may be that the lung function test was performed prior to the FENO test. The FENO test performed after the shift of work is not appropriate because working in the cement industry is a heavy task and requires the physical strength of the workers. The ATS recommended that the respiratory maneuvering factor and physical activity should have an effect on the production of FENO. Instead, a study on FENO in Norwegian cement production workers showed a lower concentration of FENO with a median of $14 \mathrm{ppb}$ (Fell et al., 2011). However, the concentrations of FENO among cement mill workers in Saudi Arabia had mean 31.71 $\pm 28.08 \mathrm{ppb}$ (Meo et al., 2014), which was almost similar with FENO concentration in cement workers of this study.

The ATS has classified that FENO level into three groups, where the lower FENO level is less than $25 \mathrm{ppb}$ and the normal FENO status in adults. The medium FENO level shows early inflammation of the lung at a concentration between $26-50 \mathrm{ppb}$. In the meantime, the highest FENO level is more than $50 \mathrm{ppb}$, where there is inflammation of the airways. This indicates that $20 \%$ of the cement workers have an intermediate allergic airways inflammation. However, $18 \%$ of the cement workers which highly contributed by manufacturing workers have eosinophilic inflammation that increased the production of FENO.

The manufacturing group had the highest percentage of workers with a high FENO level of $24.0 \%$. Then, the administrative group had $12.0 \%$ of the workers who were high in FENO level. The total cement workers showed a high FENO abnormality of $38.0 \%$. There were $21 \%$ of exposed respondents who had medium FENO levels and $9 \%$ of exposed respondents who had high FENO levels in the cement industry in Tanzania (Tungu et al., 2013). In addition, a study in Kashmir, India found that the exposed group of cement dust had a significant high FENO level with a mean of $51.349 \pm 15 \mathrm{ppb}$ (Mehraj et al., 2013).

Respirable Si dust among all cement workers showed a significant relationship to the production of FENO concentrations $(r=0.373, p=0.016)$. This was due to a significant moderate correlation between the respirable $\mathrm{Si}$ dust and the production of FENO concentration among administrative workers $(\mathrm{r}=0.646, \mathrm{p}=0.004)$. However, manufacturing workers in the cement industry have shown no significant relationship between the respirable Si dust and the production of FENO concentration $(r=0.171, p=0.436)$. Respirable As dust among all cement workers, there has been a significant relationship with the production of FENO concentration $(r=0.321, p=0.016)$. There was a significant correlation between the respirable As dust and production of FENO concentration among administrative workers ( $\mathrm{r}=$ $0.440, p=0.040)$. Manufacturing workers in the cement industry have shown a weak relationship between respirable As dust and production of FENO concentration, but no significant value $(\mathrm{r}=0.224, \mathrm{p}=0.317)$.

Respirable Cr dust among all cement workers also showed a significant relationship to the production of FENO 
concentrations $(\mathrm{r}=0.350, \mathrm{p}=0.002)$. This was due to the significant moderate correlation between the respirable $\mathrm{Cr}$ dust and the production of FENO concentration among administrative workers $(\mathrm{r}=0.521, \mathrm{p}=0.013)$. However, there was no significant relationship between the respirable $\mathrm{Cr}$ dust and the production of FENO concentration $(\mathrm{r}=$ $0.230, p=0.303$ ) between cement manufacturing workers.

\section{Influence by Working Behavior Factors}

The factors influence by working behavior on workers' exposure to respirable cement mineral dust are shown in Table 6 . The behavioral factor data of cement workers, such as the data whether the workers are noticed of their respiratory health risk, wearing a mask while working, attending respiratory or PPE training, cleaning clothes after working, and having heavy-duty work on the job task, might influence in the increasing of cement mineral dust exposure (Cecala and Thimons, 1993; Lahiri et al., 2005; Yeheyis et al., 2012). The previous studies show how the effectiveness of using N95 mask or respirator, blowing the clothes and attending training can reduce as the maximum of $95 \%, 58 \%$ and $50 \%$, respectively of exposure risk (Cecala and Thimons, 1993; Lahiri et al., 2005; Yeheyis et al., 2012). The routine of not cleaning clothes after working is significantly influenced in the increasing of cement mineral dust in administrative workers and no significantly influence in manufacturing workers. It was found that $13.2 \%$ of increased $\mathrm{Si}$ concentrations were explained by administrative workers not cleaning their clothes after working $\left(R^{2}=0.132\right)$. However, if this study is replicated with a sample drawn from the same administrative workers, $11.4 \%$ of the increased exposure to Si concentrations was explained by not cleaning clothes after working $\left(R_{\text {Adj }}^{2}=\right.$ $0.0114)$. Every increase of one standard deviation of not cleaning clothes after working among administrative workers would result in a 0.363 significant increase of respirable Si cement dust exposure $(\beta=0.363, p=0.009)$.

This also happened for the As and $\mathrm{Cr}$ concentrations, of which $9.0 \%$ and $8.3 \%$, respectively, were explained by not cleaning clothes after working. The replicated study found $R^{2}=0.074$ and $R^{2}=0.067$ for As and $\mathrm{Cr}$, respectively, among administrative workers. The increase of one standard deviation of not cleaning clothes after working among administrative workers would result in a 0.300 significant increase of respirable As cement dust exposure $(\beta=0.300$, $p=0.021)$ and a 0.288 significant increase of respirable $\mathrm{Cr}$ cement dust exposure $(\beta=0.288, p=0.027)$.

The factors influenced by wearing a mask cannot be determined since none of the administrative workers wears a mask while working. However, among all cement workers showed that not wearing mask (N95 or respirator) is the main predictor that influenced the increased exposure to respirable cement mineral dust. It was found that $18.5 \%$, $27.0 \%$, and $26.7 \%$ of the increased exposure to $\mathrm{Si}, \mathrm{As}$, and $\mathrm{Cr}$ concentrations, respectively, were explained by not wearing a mask while working among cement workers. If this study is replicated with a sample drawn from the same cement workers, $17.9 \%, 26.4 \%$, and $26.2 \%$ of the increased exposure to $\mathrm{Si}, \mathrm{As}$, and $\mathrm{Cr}$ concentrations, respectively, were explained by not wearing a mask while working.

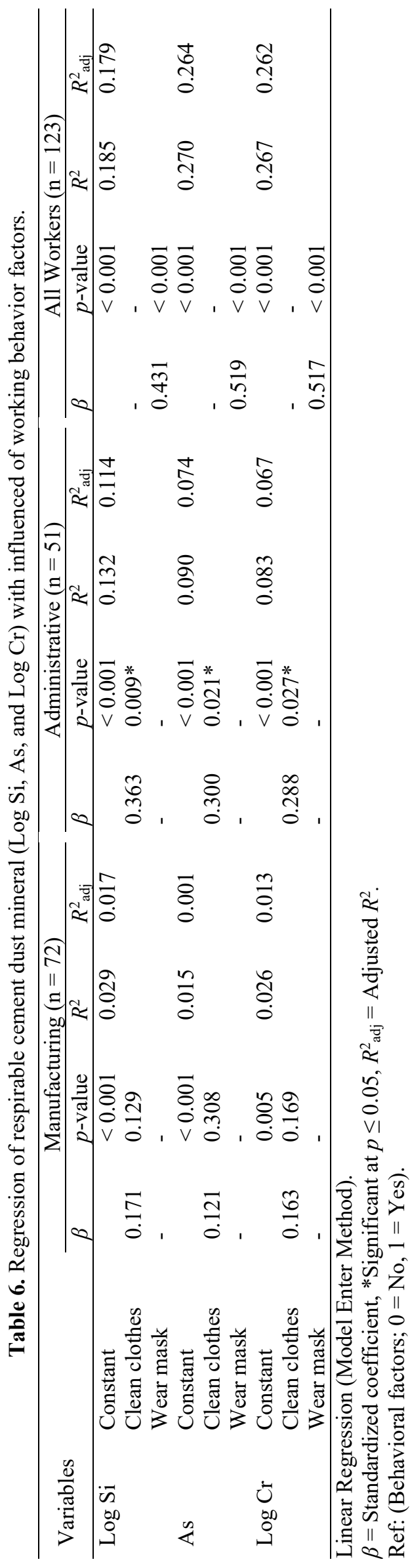


There would be significantly increased $\mathrm{Si}(\beta=0.431, p<$ $0.001)$, As $(\beta=0.519, p<0.001)$, and $\operatorname{Cr}(\beta=0.517, p<$ $0.001)$ concentrations with every increase of one standard deviation of not wearing a mask while working among cement workers. However, the behavioral of manufacturing workers such as aware on respiratory health risk, wearing a mask while working, attending respiratory or PPE training, cleaning clothes after working, and heavy-duty work on the job task have no significant influence with the increased of respirable $\mathrm{Si}, \mathrm{As}$, and $\mathrm{Cr}$ concentration.

\section{Probability Risk on Respiratory Health Effect}

Nagelkerke $\mathrm{R}^{2}=0.410$ in manufacturing workers means that $41.0 \%$ of the lung function FVC\% predicted abnormalities have been explained by exposure to Si Respirable Cement Dust concentration as in Table 7 . Thus, the prevalence having abnormalities of $\mathrm{FVC} \%$ predicted among manufacturing workers from exposure to high concentration of Si respirable cement dust after controlling other factors influenced was 19.3 times likelihood $(\mathrm{OR}=19.340,95 \% \mathrm{CI}=1.918$ 194.994). The highest predictor variables of $\mathrm{FEV}_{1} \%$ predicted by manufacturing workers were $\mathrm{Si}$ respirable cement dust. The increase in the concentration of $\mathrm{Si}$ respirable cement dust concentration was significantly associated with a 10 -fold increase in the $\mathrm{FEV}_{1} \%$ predicted status abnormality among manufacturing workers (OR = $10.159,95 \% \mathrm{CI}=1.027-100.513)$. The abnormalities of $\mathrm{FEV}_{1} \%$ predicted were 18 times likely to occur among cement workers exposed to high respirable $\mathrm{Si}$ dust $(\mathrm{OR}=$ $18.320,95 \%$ CI $=3.078-109.027)$. Meanwhile, Si was found highly influence in the abnormality of $\mathrm{FEV}_{1} \%$ predicted compared to $\mathrm{FVC} \%$ predicted among administrative workers with adjusted $\mathrm{OR}=20.953,95 \% \mathrm{CI}=5.403-182.92$ and $\mathrm{OR}=9.54,95 \% \mathrm{CI}=5.955-15.289$, respectively.

The increase in the concentration of As respirable cement dust concentration was significantly associated with a 16.6 fold increase in the FVC\% predicted abnormality among manufacturing workers $(\mathrm{OR}=16.575,95 \% \mathrm{CI}=1.725$ 159.288). The risk abnormalities of $\mathrm{FEV}_{1} \%$ predicted were significantly associated with 7.6 times greater probability of heavy work duties among manufacturing workers $(\mathrm{OR}=7.655$, $95 \% \mathrm{CI}=1.255-46.698)$. Meanwhile, the risk abnormalities of $\mathrm{FEV}_{1} \%$ predicted of heavy duty work task among all cements workers were 3.8 times more likely to occur $(\mathrm{OR}=$ 3.802, 95\% CI = 1.549-14.143). However, manufacturing workers and all cement workers who have been exposed to As respirable cement dust are unlikely to contribute to the risk abnormalities of $\mathrm{FEV}_{1} \%$ predicted. Meanwhile, exposure to As and having heavy work duties might influenced the abnormalities of $\mathrm{FEV}_{1} \%$ predicted among administrative workers with adjusted OR $=10.064(95 \% \mathrm{CI}=1.541-$ $127.347)$ and adjusted $\mathrm{OR}=5.708(95 \% \mathrm{CI}=1.025-31.780)$ respectively.

The abnormalities status of FVC\% predicted among manufacturing workers can be explained by $50.5 \%$ of $\mathrm{Cr}$ respirable cement dust as shown in Table 7 . As a result, the risk abnormalities of $\mathrm{FVC} \%$ predicted were 18 times higher after adjustment to the confounding of other factors among manufacturing workers who were exposed to $\mathrm{Cr}$ respirable cement dust $(\mathrm{OR}=18.337,95 \% \mathrm{CI}=2.379-141.318)$. The prevalence having abnormalities of $\mathrm{FEV}_{1} \%$ predicted among cement workers from exposed to a high concentration of $\mathrm{Cr}$ respirable cement dust after controlling other factors influence was 14.4 times likelihood $(\mathrm{OR}=14.408,95 \% \mathrm{CI}$ $=1.903-109.063)$. Heavy duty work tasks would increase the 5.5-fold likelihood of abnormalities of $\mathrm{FEV}_{1} \%$ predicted among manufacturing workers $(\mathrm{OR}=5.485,95 \% \mathrm{CI}=$ 1.063-28.308). The abnormalities of $\mathrm{FEV}_{1} \%$ predicted were 38 times likely to occur among administrative workers exposed to high respirable $\mathrm{Cr}$ dust $(\mathrm{OR}=37.78,95 \% \mathrm{CI}=$ 1.224-265.802) compared to the occurring of FVC\% (OR = $14.12,95 \% \mathrm{CI}=1.838-108.53$ ).

A linear regression analysis was conducted to estimate the predictors that influenced the production of FENO concentration in the study group as presented in Table 8 . Variables in the production of FENO were influenced by factors such as the concentration of respirable cement dust of $\mathrm{Si}$, As, and $\mathrm{Cr}\left(\mathrm{mg} \mathrm{m}^{-3}\right)$, smoking status, age, respiratory health risk notification, cleaning of clothing after work, and attending any respiratory disease training or training to wear proper protective equipment. Manufacturers have shown no significant relationship between exposure to respirable cement dust concentration of $\mathrm{Si}, \mathrm{As}$ and $\mathrm{Cr}$ with FENO concentration.

Si respirable cement dust had found the only predictors that influenced FENO concentration among administrative workers $(p=0.006)$ to be significant. Hence, exposure to $\mathrm{Si}$ respirable cement dust concentration $\left(\mathrm{R}^{2}=0.584\right)$ highly explained $58.4 \%$ of the FENO concentration. However, if this study is replicated with a sample taken from the same administrative workers, $35.7 \%$ of the increased production of FENO concentration is explained by exposure to $\mathrm{Si}$ respirable cement dust concentration (Adjust $\mathrm{R}^{2}=0.357$ ). In addition, As respirable cement dust was a predictor that significantly improves the predictive ability to contribute to increasing production the concentration of FENO among administrative workers $(\mathrm{p}=0.040)$. Exposure to respirable cement dust concentration $\left(\mathrm{R}^{2}=0.319\right)$ explained that $31.9 \%$ of $\mathrm{R}^{2}$ will influence the production of FENO concentration. However, if this study is replicated with a sample taken from the same manufacturing workers, $4.7 \%$ of the increased production of FENO concentration is explained by exposure to As respirable cement dust concentration (Adjust $\mathrm{R}^{2}=$ 0.047). Cr respirable Cement Dust was the only significant predictor that contributed to increasing the concentration of FENO production in administrative workers $(p=0.019)$. $37.9 \%$ of the increased production of FENO concentration was explained by exposure to $\mathrm{Cr}$ respirable cement dust concentration in administrative workers $\left(R^{2}=0.379\right)$. However, if this study is replicated with a sample taken from the same administrative workers, $13.1 \%$ of the increase in production of FENO concentration is explained by exposure to $\mathrm{Cr}$ respirable cement dust concentration in administrative cement workers (Adjust $\mathrm{R}^{2}=0.131$ ).

\section{Incremental Lifetime Cancer Risk (ILCR)}

Table 9 shows the ILCR of respirable cement mineral dust containing Si, As, and $\mathrm{Cr}$ (VI). High exposure to respirable 


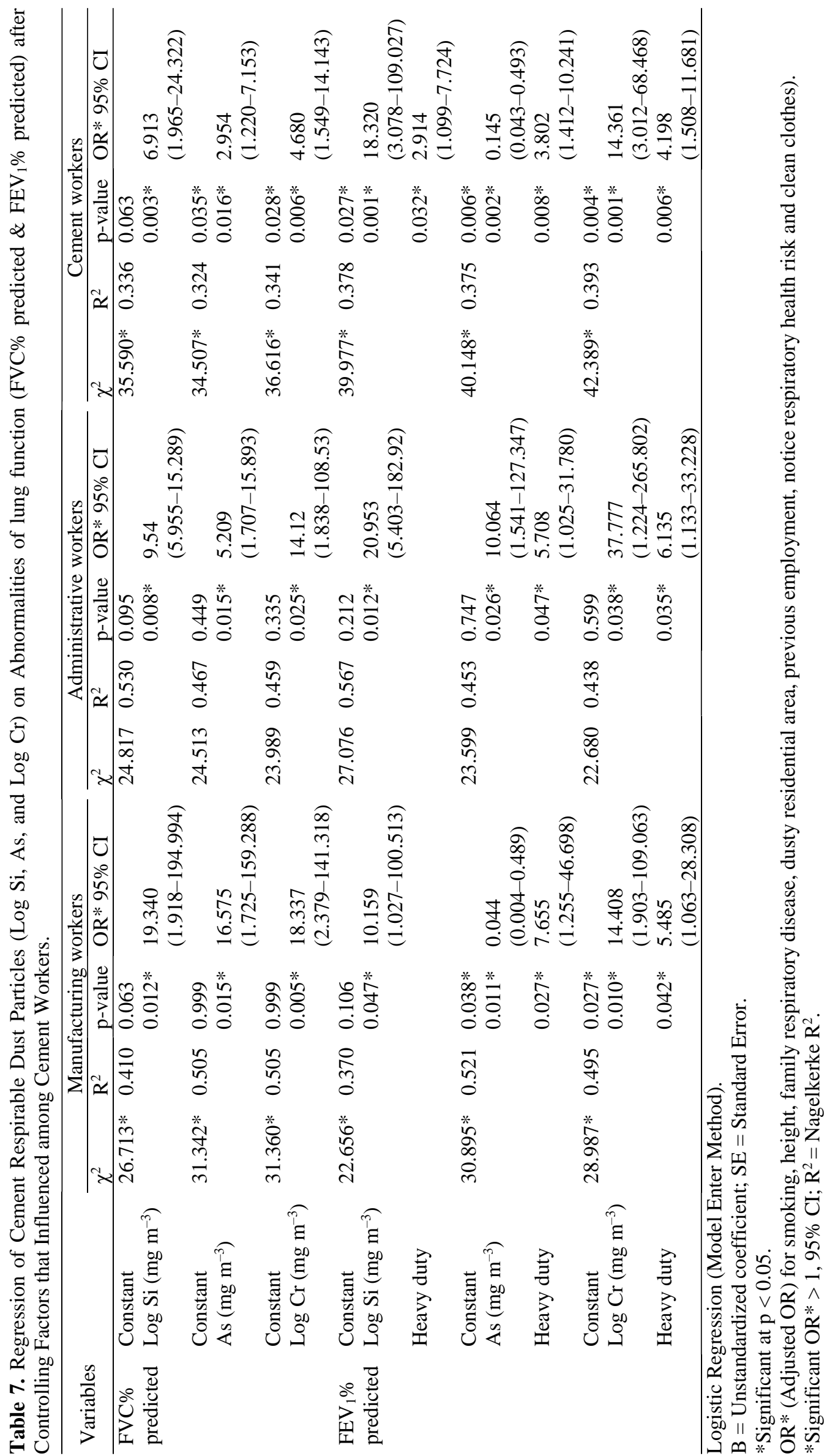


Table 8. Regression of Cement Respirable Dust Particles (Log Si, As, and Log Cr) on Log FENO Concentration after Controlling Factors that Influenced among Cement Workers.

\begin{tabular}{|c|c|c|c|c|c|c|c|c|}
\hline \multirow[t]{2}{*}{ Variables } & \multicolumn{4}{|c|}{ Administrative workers } & \multicolumn{4}{|c|}{ Cement workers } \\
\hline & $\beta$ & p-value & $\mathrm{R}^{2}$ & $* \mathrm{R}^{2}$ & $\beta$ & p-value & $\mathrm{R}^{2}$ & $* \mathrm{R}^{2}$ \\
\hline Constant & & 0.711 & 0.584 & 0.357 & & 0.989 & 0.303 & 0.180 \\
\hline $\log \operatorname{Si}\left(\mathrm{mg} \mathrm{m}^{-3}\right)$ & 0.733 & $0.006^{*}$ & & & 0.386 & $0.013^{*}$ & & \\
\hline Clean clothes & & & & & -0.383 & $0.014^{*}$ & & \\
\hline Constant & & 0.590 & 0.319 & 0.047 & & -0.592 & 0.269 & 0.151 \\
\hline As $\left(\mathrm{mg} \mathrm{m}^{-3}\right)$ & 0.533 & $0.040^{*}$ & & & 0.329 & $0.031 *$ & & \\
\hline Clean clothes & & & & & -0.377 & $0.014 *$ & & \\
\hline Constant & & 0.426 & 0.379 & 0.131 & & 0.496 & 0.262 & 0.143 \\
\hline $\log \operatorname{Cr}\left(\mathrm{mg} \mathrm{m}^{-3}\right)$ & 0.582 & $0.019 *$ & & & 0.317 & $0.038 *$ & & \\
\hline Clean clothes & & & & & -0.345 & $0.025 *$ & & \\
\hline
\end{tabular}

Linear Regression (Model Enter Method)

$\mathrm{B}=$ Unstandardized coefficient $\mathrm{SE}=$ Standard Error,

$\beta=$ Standardized coefficient

*Significant at $\mathrm{p} \leq 0.05$.

Ref: $($ Clean clothes; $0=$ No, $1=$ Yes $)$.

Table 9. ILCR of respirable cement mineral dust ( $\mathrm{Si}, \mathrm{As}$, and $\mathrm{Cr}(\mathrm{VI})$ ).

\begin{tabular}{|c|c|c|c|c|}
\hline Variables & Risk assessment & Manufacturing & Administrative & All cement workers \\
\hline \multirow[t]{2}{*}{$\mathrm{Si}$} & ILCR & $29.81 \times 10^{-4}$ & $4.14 \times 10^{-4}$ & $19.17 \times 10^{-4}$ \\
\hline & $\mathrm{ILCR}_{\mathrm{pc}}$ & $0.45 \times 10^{-4}$ & $0.06 \times 10^{-4}$ & $0.29 \times 10^{-4}$ \\
\hline \multirow[t]{2}{*}{ As } & ILCR & $734.87 \times 10^{-4}$ & $173.62 \times 10^{-4}$ & $499.51 \times 10^{-4}$ \\
\hline & $\mathrm{ILCR}_{\mathrm{pc}}$ & $11.02 \times 10^{-4}$ & $2.60 \times 10^{-4}$ & $7.49 \times 10^{-4}$ \\
\hline \multirow[t]{2}{*}{$\mathrm{Cr}(\mathrm{VI})$} & ILCR & $4707.90 \times 10^{-4}$ & $490.38 \times 10^{-4}$ & $2939.26 \times 10^{-4}$ \\
\hline & $\mathrm{ILCR}_{\mathrm{pc}}$ & $70.62 \times 10^{-4}$ & $7.36 \times 10^{-4}$ & $44.09 \times 10^{-4}$ \\
\hline
\end{tabular}

Si dust in the cement industry contributes to a high probability of developing cancer among manufacturing workers at 29.81 $\times 10^{-4}$ times compared to administrative workers at $4.14 \times 10^{-4}$ times. This means that in every 10,000 manufacturing workers, 29.81 workers have a high tendency of developing cancer due to exposure to respirable $\mathrm{Si}$ in cement mineral dust. Meanwhile, the administrative group has 4.14 workers with high chances of developing cancer among 10,000 workers exposed to respirable $\mathrm{Si}$ in cement mineral dust. If considering the prevention and control measures implemented in this industry, the ILCR after exposure to respirable Si cement dust is reduced to 0.45 among $10,000\left(0.45 \times 10^{-4}\right)$ manufacturing workers and 0.06 among $10,000\left(0.06 \times 10^{-4}\right)$ administrative workers.

However, in this study, the administrative workers worked in an office and did not receive prevention and control measures like the manufacturing workers. Thus, the cancer risk for manufacturing workers was considered with prevention and control measures ( $\mathrm{ILCR}_{\mathrm{pc}}$ ), while the cancer risk for administrative workers was not considered with prevention and control measures (ILCR). If the data were compared with NIOSH recommendations of the minimum levels for cancer risk exposure among workers, the manufacturing group had an acceptable risk of exposure to respirable Si dust. In contrast, the administrative group of workers exceeded 1 in 10,000 cases $\left(1 \times 10^{-4}\right)$, the acceptable limit set by the NIOSH (Whittaker et al., 2017).

Manufacturing workers had a high probability of developing cancer due to exposure to As in respirable cement dust at
$734.87 \times 10^{-4}$ times. After considering prevention and control measures, the mean $\mathrm{ILCR}_{\mathrm{pc}}$ for exposure to respirable As cement dust was 11.02 among $10,000\left(11.02 \times 10^{-4}\right)$ manufacturing workers. Exposure to As in respirable cement dust without prevention and control measures had a high probability of developing cancer among administrative workers at 173.62 for every $10,000\left(173.62 \times 10^{-4}\right)$ workers. The exposure to high concentrations of respirable As cement dust among both manufacturing and administrative workers did not meet the minimal acceptable limit set by the NIOSH and had a high risk of developing cancer in a lifetime.

The total $\mathrm{Cr}$ concentrations in this respirable cement dust were assumed to be $\mathrm{Cr}$ (VI) due to the high oxidizing process of $\mathrm{Cr}$ (III) in cement production. The respirable $\mathrm{Cr}$ (VI) dust exposure among manufacturing and administrative cement workers had a high probability of lifetime cancer risk at $4707.90 \times 10^{-4}$ and $490.38 \times 10^{-4}$ times, respectively. It was found that 70.62 out of 10,000 manufacturing workers are expected to develop cancer due to exposure to $\mathrm{Cr}$ (VI) respirable dust even after reducing for prevention and control measures. However, the $\mathrm{ILCR}_{\mathrm{pc}}$ among manufacturing workers and the ILCR among administrative workers greatly exceeded the minimal level for lifetime cancer risk according to the NIOSH.

A reviewed study on workers' health risk assessment in the various working industry was presented as in Table 10 . A study on exposure to $\mathrm{Cr}$ (VI) and As in Upper Silesia, Poland, found that the respondents were at high risk of cancer due to urban traffic exposure, with $\mathrm{Cr}(\mathrm{VI})=18.00 \times$ 
$10^{-4}$ (Widziewicz et al., 2016). In addition, Cr (VI) among manufacturing workers in e-waste factory's workers in Shanghai, China, exceeded the acceptable limit at $3.45 \times 10^{-4}$ (Fang et al., 2013). Meanwhile, Yang et al. (2018) found that steel welders were highly exposed with $\mathrm{Cr}$ (VI), with a concentration mean of $0.504 \pm 0.295 \mathrm{mg} \mathrm{m}^{-3}$, and the workers' cancer risk was 1.4 times. Welding for pipeline construction has a high probability of cancer risk compared to welding for pressure container manufacture due to pipeline construction is in a confined area with poor ventilation. The ILCR for $\mathrm{Cr}$ (VI) also was found higher in an office building in the urban area in Malaysia with $0.92 \times 10^{-4}$ which almost near to the acceptable limit by NIOSH (Othman et al., 2015)

The probability risk of lifetime carcinogenic cause from exposure to As dust in adults was $0.51 \times 10^{-4}$ (Widziewicz et al., 2016). Inhalation of As cement dust caused $0.007 \times$ $10^{-4}$ times greater likelihood of developing cancer (Addo et al., 2016). It was estimated that the $95 \%$ cancer risk due to exposure to As from industrial emission in Xiaogang, Taiwan is $0.04 \times 10^{-4}$ (Tsai et al., 2019). The previous study found less of As cancer risk due to the concentration exposure is lower and below the permissible exposure limit.

Construction workers exposed to crystalline Si had an ILCR of $0.77 \times 10^{-4}$ times, but this was reduced to $0.16 \times$ $10^{-4}$ and $0.26 \times 10^{-4}$ times after considering engineering control and wearing a comfort mask, respectively (Yeheyis et al., 2012). This shows that factor control reduces the risk of exposure.

Table 10. Reviewed study on workers health risk assessment.

\begin{tabular}{|c|c|c|c|c|}
\hline Authors & Subject/Area & Mineral & Exposure Concentration & Risk Assessment \\
\hline $\begin{array}{l}\text { Fang et al. } \\
(2013)\end{array}$ & $\begin{array}{l}\text { E-waste factory's } \\
\text { workers in Shanghai, } \\
\text { China }\end{array}$ & $\mathrm{Cr}(\mathrm{VI})$ & - & $\begin{array}{l}\text { - } \mathrm{ILCR}=\mathrm{Cr}(\mathrm{VI})=3.45 \times 10^{-4} \\
\text { - } \mathrm{HQ}=\mathrm{Cr}(\mathrm{VI})=0.005\end{array}$ \\
\hline $\begin{array}{l}\text { Othman et al. } \\
\text { (2015) }\end{array}$ & $\begin{array}{l}\text { Office building at } \\
\text { urban area } \\
\text { (City in Negeri } \\
\text { Sembilan, Malaysia) }\end{array}$ & $\mathrm{Cr}(\mathrm{VI})$ & $0.493 \pm 0.421 \mathrm{mg} \mathrm{m}^{-3}$ & $\begin{array}{l}\text { - ILCR: } \mathrm{Cr}(\mathrm{VI})=0.92 \times 10^{-4} \\
\text { - HQ: } \mathrm{Cr}(\mathrm{VI})=0.22\end{array}$ \\
\hline $\begin{array}{l}\text { Yang et al. } \\
\text { (2018) }\end{array}$ & $\begin{array}{l}\text { Steel welders in } \\
\text { Taiwan } \\
\text { - Pipeline } \\
\text { construction } \\
\text { - Pressure container } \\
\text { manufacture }\end{array}$ & $\mathrm{Cr}(\mathrm{VI})$ & $0.504 \pm 0.295 \mathrm{mg} \mathrm{m}^{-3}$ & $\begin{array}{l}\text { - ILCR for pipeline } \\
\text { construction: } \mathrm{Cr}(\mathrm{VI})=1.40 \\
\text { - ILCR for pressure container } \\
\text { manufacture: } \mathrm{Cr}(\mathrm{VI})=130.00 \\
\times 10^{-4}\end{array}$ \\
\hline $\begin{array}{l}\text { Mousavian et al. } \\
\text { (2017) }\end{array}$ & $\begin{array}{l}\text { Steel industries } \\
\text { workers in Iran }\end{array}$ & $\mathrm{Cr}(\mathrm{VI})$ & $0.05 \mathrm{mg} \mathrm{m}^{-3}$ & $\begin{array}{l}\text { - } \mathrm{ILCR}=50.00 \times 10^{-4} \\
\text { - } \mathrm{HQ}=0.3\end{array}$ \\
\hline $\begin{array}{l}\text { Widziewicz et } \\
\text { al. (2016) }\end{array}$ & $\begin{array}{l}\text { Adult (19-75.5 years)- } \\
\text { Urban traffic site- } \\
\text { Upper Silesia, Poland }\end{array}$ & $\begin{array}{l}\text { - } \mathrm{Cr}(\mathrm{VI}) \\
\text { - } \mathrm{As}\end{array}$ & - & $\begin{array}{l}\text { - ILCR: } \mathrm{Cr}(\mathrm{VI})=18.00 \times 10^{-4} \text {, } \\
\text { As }=0.51 \times 10^{-4} \\
\text { - ILCR for Cr }(\mathrm{VI}) \text { and As was } \\
\text { above acceptable limit }\end{array}$ \\
\hline $\begin{array}{l}\text { Sulong et al. } \\
\text { (2017) }\end{array}$ & $\begin{array}{l}\text { Adult (18-70 years)- } \\
\text { Kuala Lumpur city } \\
\text { centre, Malaysia }\end{array}$ & $\begin{array}{l}-\mathrm{Cr}(\mathrm{VI}) \\
\bullet \mathrm{As}\end{array}$ & - & $\begin{array}{l}- \text { ILCR after haze: } \mathrm{Cr} \\
(\mathrm{VI})=0.13 \times 10^{-4}, \mathrm{As}=0.003 \times \\
10^{-4} \\
-\mathrm{HQ} \text { after haze: } \mathrm{Cr}(\mathrm{VI})=0.18 \text {, } \\
\mathrm{As}=0.002\end{array}$ \\
\hline $\begin{array}{l}\text { Yeheyis et al. } \\
(2012)\end{array}$ & Construction workers & Crystalline $\mathrm{Si}$ & $0.22 \pm 5.3 \mathrm{mg} \mathrm{m}^{-3}$ & $\begin{array}{l}\text { - ILCR: } \mathrm{Si}=0.77 \times 10^{-4} \\
\text { - ILCR with Engineering } \\
\text { control: } \mathrm{Si}=0.16 \times 10^{-4} \\
\text { - ILCR with wearing comfort } \\
\text { mask control: } \mathrm{Si}=0.26 \times 10^{-4} \\
\text { - HQ: } \mathrm{Si}=22.00 \\
\text { - HQ with Engineering control: } \\
\mathrm{Si}=4.83 \\
\text { - HQ with wearing comfort } \\
\text { mask control: } \mathrm{Si}=8.01\end{array}$ \\
\hline
\end{tabular}




\section{Hazard Quotient (HQ)}

The HQ value for exposure to respirable $\mathrm{Si}$, $\mathrm{As}$, and $\mathrm{Cr}$ (VI) cement dust highly exceeded the minimal reference value among manufacturing and administrative cement workers, as shown in Table 11. The minimum acceptable value of HQ is less than or equal to 1 , which is considered having a negligible hazard or the least adverse effects (U.S. EPA, 2015; IARC, 2019). However, the minimal reference value of an $\mathrm{HQ}$ with a value less than 1 is the threshold limit of dose-response concentration for non- cancerous disease and fits regulatory compliance; it does not indicate the statistical probabilities of non- cancerous disease risk. Even after the reduction of prevention and control measures, the $\mathrm{HQ}_{\mathrm{pc}}$ value of respirable cement mineral dust was unacceptable. Yeheyis et al. (2012) was found a high level of HQ value with 22.00 and after the reduction of engineering control and wearing a comfort mask, the $\mathrm{HQ}_{\mathrm{pc}}$ is above the acceptable value as shown in Table 10 .

Through workplace observation, this cement industry was equipped and implemented various engineering control measures, such as local exhaust ventilation (LEV) with a beg filter system, an air dryer system, and an air slide conveyor system to reduce dispersion and suspension of cement dust in the working atmosphere in the cement production factory. Besides, the manufacturing workers were provided with a suitable N95 mask and a respirator while working. The management of the cement industry also conducted training regarding the use of PPE and health awareness.

However, the management might not be aware that the health risk to administrative workers is somewhat similar to that of manufacturing workers, even though they are not directly in contact with cement mineral dust. Administrative workers also neglected to wear an N95 mask or respirator and did not attend any training regarding the use of PPE and health awareness. The regression factors show that not wearing a mask among cement workers is the main predictor that significantly influenced the increased exposure to respirable cement mineral dust. Besides, the habit of the administrative workers, not cleaning their cloth after working also have significantly influenced the increasing exposure to respirable cement dust. Thus, they had a high probability of cancer and non-cancer risk associated with their working behavioral factors, especially not wearing PPE or protected mask and not cleaning cloth after working.

Meanwhile, the exposure to respirable cement dust among manufacturing workers shows no significant influence by their behavioral factors due to most of them are following good behavioral. The distance between the cement production area and quarries and the administrative office is less than
$200 \mathrm{~m}$. Even though the administrative workers work in an office building, respirable cement dust can enter through a small hole and become entrapped in the building since no ventilation system was applied in this office. The U.S. EPA and NIOSH have recommended the use of a ventilation system equipped with a high-efficiency particulate air (HEPA) cleaning filter system for the indoor air quality to reduce the exposure of contaminants and maintain a healthy indoor environment (NIOSH, 2018; U.S. EPA, 2018).

A study in Korea from 2008 to 2012 found various cancer effects from cement exposure, with 228 cases in men and 76 cases in women of lung and bronchial cancer; these included 18 cases of men with larynx cancer, 5 cases of women with salivary gland cancer, and 3 cases of men with nasopharynx cancer (Eom et al., 2016). Dietz et al. (2003) concluded that cement workers are at high risk of developing laryngeal cancer due to exposure to hazardous cement dust. It was also determined that Portland cement workers who had worked without any respiratory protection developed obstructive respiratory disease (Al-Neaimi et al., 2001) and had a high prevalence of respiratory signs and symptoms (Manjula $e t$ al., 2003; Kamaludin et al., 2018a).

Inhalation of respirable Si dust will be deposited in airways and alveoli, then phagocytized by macrophages (Balakrishnan et al., 2019). This will activate the proinflammatory and profibrotic pathway that leads to cell necrosis, autophagy and release of cytotoxic, inflammatory cytokines and arachidonic metabolites (Barnes, 2019). Subsequently causing alveolar inflammation and fibrosis (Balakrishnan et al., 2019; Barnes et al., 2019). After adjusting for various factors, cement manufacturing workers were 2.31 times more likely to get cancer after exposure to respirable Si dust (Cassidy et al., 2007). In Korea, the major lung cancer among workers was $23.5 \%$ caused by exposure to crystalline silica (Ahn and Jeong, 2014).

A study on cement mineral dust exposure found that the inhalation of $\mathrm{Cr}(\mathrm{VI})$ dust without prevention and control measures caused $0.008 \times 10^{-4}$ times greater likelihood of developing cancer, while inhalation of As cement dust caused $0.007 \times 10^{-4}$ times greater likelihood of developing cancer (Addo et al., 2016). IARC had reported that the inhalation of $\mathrm{Cr}(\mathrm{VI})$ in the long term could cause carcinogenesis, immunological disorder, and fibrosis (U.S. EPA, 1998; Junaid et al., 2016). The rapid permeability of $\mathrm{Cr}$ (VI) chemical properties into cell membranes and interaction with intracellular protein and nucleic acids are very toxic to the human body (Mishra and Bharagava, 2016). A great concern was highlighted on the health risk regarding the exposure to $\mathrm{Cr}$ (VI), which potentially causes cancer, dermatitis, asthma,

Table 11. HQ of respirable cement mineral dust ( $\mathrm{Si}$, As, and $\mathrm{Cr}(\mathrm{VI})$ ).

\begin{tabular}{lllll}
\hline Variables & Risk assessment & Manufacturing & Administrative & All cement workers \\
\hline $\mathrm{Si}$ & $\mathrm{HQ}$ & 531.91 & 228.16 & 405.96 \\
& $\mathrm{HQ}$ & 7.98 & 3.42 & 6.09 \\
$\mathrm{As}$ & $\mathrm{HQ}$ & 109.17 & 79.59 & 96.76 \\
& $\mathrm{HQ}$ & 1.64 & 1.19 & 1.45 \\
$\mathrm{Cr}(\mathrm{VI})$ & $\mathrm{HQ}$ & 5235.41 & 1656.65 & 3734.64 \\
& $\mathrm{HQ}_{\mathrm{pc}}$ & 78.53 & 24.85 & 56.02 \\
\hline
\end{tabular}


chronic bronchitis, hypertension, metabolic syndrome and many others (Mikoczy and Hagmar, 2005; Junaid et al., 2016). The office workers have a high probability of lifetime cancer risk due to exposure $\mathrm{Cr}(\mathrm{VI})$ at the urban area with exposure from motor vehicle and industrial emission (Othman et al., 2015).

Inhalation of As may cause rhinitis, pharyngitis, laryngitis, and trachea bronchitis, and tracheal and bronchial haemorrhage may complicate serious cases, according to the International Programme on Chemical Safety. Dermal changes are significant indicators of chronic As toxicity following inhalation or oral exposure (Public Health England, 2016). Inhalation and ingestion of As were found to have significantly increased the possibility of lung cancer among the population risk (Smith et al., 2009). Respirable to the high concentration of As can cause a sore throat and lung inflammation, while exposure in more extended periods can cause liver and kidney damage and a shortage of red and white blood cells (American Cancer Society, 2019).

The use of personal respiratory protection was found to decrease the respiratory health prevalence of cement workers from $65 \%$ to $35 \%$ (Nordby et al., 2011). Moreover, several studies have found that respiratory health performance has a significant relationship with the effectiveness of PPE (Merenu et al., 2007; Zeleke et al., 2010; Tungu et al., 2014). The risk of exposure to respirable $\mathrm{Si}, \mathrm{As}$, and $\mathrm{Cr}$ (VI) cement dust can be reduced by $70-86 \%$ with the implementation of engineering controls (Lahiri et al., 2005).

A study in the cement industry of Central Ethiopia found that workers had a significantly increased likelihood of 1.2 of having chronic respiratory diseases due to not attending OSH training (Mekasha et al., 2018). Not attending training on $\mathrm{OSH}$ regarding exposure to respirable dust caused a 2.73 times greater likelihood of developing chronic respiratory symptoms among cement workers (Gizaw et al., 2016), which is consistent with other studies (Ahmed Shafik and Abd El-Mohsen, 2012; Tungu et al., 2014).

This study revealed that administrative workers also had a high tendency of ILCR and non-cancerous disease risk and exceeded the acceptable limit. This was due to the lack of prevention and control measures in the office building, and the workers themselves were not aware of their own risk. The respirable dust that was dispersed from the cement production was small enough to penetrate the lungs. All cement workers in either the production line or the management department should have been protected once they entered the premises. The cement industry should review the effectiveness of and attendance at the training provided regarding respiratory health and the use of PPE. Behavior-based safety was highly related with the working hazard and preventing unsafe behavior such as not wearing proper PPE, absence from training, notification of risk, and neglect of self- hygiene (Zerguine et al., 2016).

The dust particle may be deposited and retained in the respiratory tract in several periods before it was expelled via exhalation or deeply penetrate the lung depending on the particle size fraction and method of clearance (Martin et al., 2014). The respirable dust with size less than $4 \mu \mathrm{m}$ can deposit in bronchi and bronchioles and retain in hours to weeks before absorption through airways epithelium into the blood, lymphatic systems, and phagocytosis (Martin et al., 2014).

Inhalation of respirable Si dust will deposit in airways and alveoli then phagocytised by macrophages (Balakrishnan et al., 2019). This will activate the proinflammatory and profibrotic pathway that leads to cell necrosis, autophagy and release of cytotoxic, inflammatory cytokines and arachidonic metabolites (Barnes et al., 2019). Subsequently causing alveolar inflammation and fibrosis (Barnes et al., 2019; Balakrishnan et al., 2019). The exposure to crystalline Si can bioaccumulate in the lung and cause a build-up connective tissues known as silicosis (Nakladalova et al., 2018). The repeated exposure to airborne $\mathrm{Si}$ will retain and accumulate in the lung tissues even after years of exposure cessation (ATSDR, 2019).

The respirable to cement dust containing $\mathrm{Si}$ will cause Silicosis that involving in fibronodular lung disease of primary pneumoconiosis. The Occupational Safety and Health Administration in the United States prescribe for low or moderate exposure to $\mathrm{Si}$ dust is associated with chronic silicosis after 15 to 20 years. While after 5-10 years or few months until two years of exposure to silica dust will associate with accelerated silicosis and acute silicosis respectively (OSHA, 2010; Nakladalova et al., 2018; Balakrishnan et al., 2019). The acute silicosis by the accumulation of granular lipoproteinaceous material in alveolar can be caused by the higher exposure to Si dust (Hutyrova et al., 2015; Nakladalova, et al., 2018). Meanwhile, chronic silicosis happened when the pulmonary alveolar spaces were accumulated with eosinophilic proteinaceous which is developed by pulmonary silicoproteinosis and influenced by the increased concentration of various inflammatory mediators and fibrogenic (Greenberg et al., 2007).

In a low dose of exposure, $\mathrm{Cr}$ (VI) can be reduced to $\mathrm{Cr}$ (III) by the epithelial lining fluid and pulmonary alveolar macrophage in the lower respiratory tract and detoxification through urination. However, the balance of $\mathrm{Cr}$ (VI) that exists between the extracellular can enter cells and toxified the cell. The damage of cellular components by the reduction process of $\mathrm{Cr}(\mathrm{VI})$ will generate free radicals and DNA damage (ATSDR, 2012). This happened when the reactive $\mathrm{Cr}$ (V/IV) intermediates were formed during the reduction process react with hydrogen peroxide $\left(\mathrm{H}_{2} \mathrm{O}_{2}\right)$ to generate a spectrum of reactive oxygen species (ROS) that containing hydroxyl radicals, singlet oxygen, superoxide and Hydrogen Peroxide through the Fenton pathway (Wang et al., 2017). The Cr (VI) can be yearly accumulated in the human body and remain in plasma when it enters red blood cells via phosphate and sulfate anion exchange carrier (ATSDR, 2012). Exposed to $\mathrm{Cr}$ (VI) dust in the repetitive and prolonged duration will cause damage to the mucous membrane in respiratory airways leads to ulceration and severely causes perforation of the septum (ATSDR, 2012).

Industrial exposure of As contains the total of Arsenate and Arsenite (IARC, 2012). Arsenate can disrupt the formation of Adenosine triphosphate (ATP) by subtracting phosphate to reacts with glucose and resembles glucose-6-phosphate into glucose-6-arsenate (Kuivenhoven and Mason, 2019). Glucose-6-phosphate is essential in glycolysis and the 
generation of ATP as a central metabolite that transfers energy molecules (Dunn and Grider, 2020). Arsenite can cause dysregulation and inhibition of protein and enzyme multiplication by reacting with thiol and sulfhydryl groups (Kuivenhoven and Mason, 2019). A vital enzyme in the citric acid cycle; Pyruvate dehydrogenase (PDH) enzyme can disrupt the impairment of cellular respiration and ATP formation due to loss of dithiol for the enzyme activation (Kuivenhoven and Mason, 2019). Exposed to As in the long period can lead to conjunctivitis, irritation of the throat and respiratory tract, and perforation of the nasal septum (ATSDR, 2014). The excretion rate of Arsenite is lower than Arsenate and organic As which causes the compound to retain in the body organ (Kuivenhoven and Mason, 2019).

\section{CONCLUSIONS}

Cement contains a variety of minerals that can be a hazardous risk to human health, especially to cement workers. The minerals contained in cement dust might cause respiratory problems among workers. This study showed that cement workers were exposed to respirable $\mathrm{Si}, \mathrm{As}$, and $\mathrm{Cr}$ dust at a level high above the permissible exposure limit set by the Malaysian government. Manufacturing workers of the cement industry have a high risk of getting lifetime cancer and non-cancer diseases because of the exposure to As and Cr dust even after the implementation of prevention and control systems. Administrative workers have more than $31.9 \%$ tendency in the production of FENO concentration with exposure to cement dust particle content with $\mathrm{Si}$, As and $\mathrm{Cr}$. The Administrative workers also shows high prevalence of getting abnormalities of $\mathrm{FEV}_{1} \%$ predicted of lung function compared with manufacturing workers. Thus, administrative workers are more risk compared to manufacturing workers due to absenteeism of prevention and control system to reduce their exposure effects. After reducing for control factors, the $\mathrm{HQ}_{\mathrm{pc}}$ of the workers for exposure to $\mathrm{Si}$, As, and $\mathrm{Cr}$ (VI) still exceeded the threshold limit value. The main predictor for behavioral factors among cement workers is not wearing the N95 mask or respirator while working especially for administrative workers who then followed by not cleaning their clothes after working. Therefore, it is highlighted in this study that indirect exposure, such as the administrative workers of the cement industry, also should receive a prevention and control system to reduce their risk of exposure. The previous study has found the effectiveness of prevention and control systems that can be applied by the industry to reduce the exposure risk among the workers. This would be the justification for the behavioral factors did not significantly influence the manufacturing workers' exposure due to they are following the good behavioral factors.

These findings represent the risk probability analysis of cancerous and non- cancerous disease risk among cement workers regarding exposure to respirable $\mathrm{Si}, \mathrm{As}$, and $\mathrm{Cr}$ (VI) in cement mineral dust. More research is needed on cancer and non-cancer health assessment, which may lead to extrapolation that more directly indicates specific diseases among cement workers.

\section{ACKNOWLEDGEMENTS}

The authors would like to express their gratitude to the Faculty of Medicine and Health Sciences, Universiti Putra Malaysia, the cement factory and all of the school participate in this study for their cooperation and valuable assistance in completing this research. This project was funded by Universiti Putra Malaysia grant (Project Code: GPIPS/2017/9527800).

\section{REFERENCES}

Achternbosch, M., Brautigam, K.R., Hartlieb, N., Kupsch, C., Richers, U. and Stemmermann, P. (2005). Impact of the use of waste on trace element concentrations in cement and concrete. Waste Manage. Res. 23: 328-337. https://doi.org/10.1177/0734242X05056075

Addo, M.A., Darko, E.O., Gordon, C., Davor, P., Ameyaw, F., Affum, H., Gbadago, J.K. and Dzide, S. (2016). Human health risk assessment of airborne trace elements for human receptors in the vicinity of the diamond cement factory, Volta Region, Ghana. Int. J. Sustain. Dev. Plan 11: 522-536. https://doi.org/10.2495/SDP-V11-N4-522-536

Agency for Toxic Substances and Disease Registry (ATSDR) (2012). Toxicological profile for Chromium. Atlanta, GA: U.S. Department of Health and Human Services, Public Health Service.

Agency for Toxic Substances and Disease Registry (ATSDR) (2014). Toxic substances portal - Arsenic trioxide. https://www.atsdr.cdc.gov/MMG/MMG.asp?id $=1200 \&$ tid $=279$

Agency for Toxic Substances and Disease Registry (ATSDR) (2019). Toxicological profile for Silica. Atlanta, GA: U.S. Department of Health and Human Services, Public Health Service.

Ahmed Shafik, S. and Abd El-Mohsen, A.S. (2012). Occupational health: Health promotion program to improve health workers in Tourah cement factory. J. Am. Sci. 8: 486-496. https://doi.org/10.7537/marsjas080312.65

Ahn, Y.S. and Jeong, K.S. (2014). Epidemiologic characteristics of compensated occupational lung cancers among Korean workers. J. Korean Med. Sci. 29: 14731481. https://doi.org/10.3346/jkms.2014.29.11.1473

Al-Neaimi, Y.I., Gomes, J. and Lloyd, O.L. (2001). Respiratory illnesses and ventilatory function among workers at a cement factory in a rapidly developing country. Occup. Med. 51: 367-373. https://doi.org/10.1093/occmed/51.6.367

American Cancer Society (ACS) (2019). Arsenic and Cancer Risk. https://www.cancer.org/cancer/cancercauses/arsenic.html

American Conference of Government Industrial Hygienist (ACGIH) (2005). Threshold limit values for chemical substances and physical agents and biological exposure indices. Cincinnati $(\mathrm{OH})$, USA.

American Thoracic Society (ATS) (2015). What are the signs and symptoms of COPD? https://www.thoracic.org/copdguidelines/for-patients/what-are-the-signs-and-symptomsof-copd.php

American Thoracic Society and European Respiratory 
Society (ATS/ERS) (2005). ATS/ERS Recommendations for Standardized Procedures for the Online and Offline Measurement of Exhaled Lower Respiratory Nitric Oxide and Nasal Nitric Oxide, 2005. Am. J. Respir. Crit. Care Med. 171: 912-930. https://doi.org/10.1164/rccm.20040 6-710ST

Aminian, O., Aslani, M. and Haghighi, K.S. (2014). Crossshift study of acute respiratory effects in cement production workers. Acta Med. Iran. 52: 146-152.

Amran, S., Latif, M.T., Khan, M.F., Goh, E., Leman, A.M. and Jaafar, S.A. (2017). Underestimation of Respirable Crystalline Silica (RCS) compliance status among the granite crusher operators in Malaysian quarries. Air Qual. Atmos. Health 10: 371-379. https://doi.org/10.1007/s118 69-016-0439-7

Attfield, M.D. and Costello, J. (2004). Quantitative exposure-response for Silica dust and lung cancer in Vermont granite workers. Am. J. Ind. Med. 45: 129-138. https://doi.org/10.1002/ajim.10348

Bae, S., Hikaru, F., Kanematsu, M., Yoshizawa, C., Noguchi, T., Yu, Y. and Ha, J. (2017). Removal of hexavalent Chromium in Portland cement using ground granulated blast-furnace slag powder. Materials 11: 11 . https://doi.org/10.3390/ma11010011

Balakrishnan, B., Mehta, S., Ouelette, D.R., Talavera, F., Mosenifar, Z., Varkey, B. Tino, G. and Varkey, A.B. (2019). Silicosis. Medscape. https://emedicine.medscape. com/article/302027-overview\#a4

Barnes, H., Goh, N.S.L., Leong, T.L. and Hoy, R. (2019). Silica-associated lung disease: An old-world exposure in modern industries. Respirology 24: 1165-1175. https://doi.org/10.1111/resp.13695

Barnes, P.J. (2006). Drugs for asthma. Br. J. Pharmacol. 147: 297-303. https://doi.org/10.1038/sj.bjp.0706437

Bleam, W.F. (2012). Chapter 10-Risk assessment. In Soil and environmental chemistry, Academic Press, pp. 409-447. https://doi.org/10.1016/B978-0-12-415797-2.00010-8

Cassidy, A., Mannetje, A., Van Tongeran, M., Field, J.K., Zaridze, D., Dabrowska, N.S., Rudnai, P., Lissowska, J., Fabianova, E., Mates, D., Bencko, V., Foretova, L., Janout, V., Fevotte, J., Fletcher, T., Brennan, P. and Boffeta, P. (2007). Occupational exposure to crystalline silica and risk of lung cancer: A multicenter case-control study in Europe. Epidemiology 18: 36-43. https://doi.org/10.1097/ 01.ede.0000248515.28903.3c

Cecala, A.B. and Thimons, E.D. (1993). Tips for reducing dust from secondary sources during bagging. Powder Bulk Eng. 7: 77-84.

Cecala, A.B., Timko, R.J. and Prokop, A.D. (2000). Methods to lower the dust exposure of bag machine operators and bag stackers. Appl. Occup. Environ. Hyg. 15: 751-765. https://doi.org/10.1080/10473220050129392

Department of Environment (2014). Best available techniques guidance document on non-metallic (mineral) industry. https://www.doe.gov.my/portalv1/wp-content/uploads/2 014/07/BEST-AVAILABLE-TECHNIQUES-GUIDAN CE-DOCUMENT-ON-NON-METALLIC-MINERALINDUSTRY.pdf

Dietz, A., Ramroth, H., Urban, T., Ahrens, W. and Becher,
H. (2003). Exposure to cement dust, related occupational groups and laryngeal cancer risk: Results of a population based case-control study. Int. J. Cancer 108: 907-911. https://doi.org/10.1002/ijc.11658

Dunn, J. and Grider, M.H. (2020). Physiology, Adenosine Triphosphate (ATP). StatPearls Publishing. https://www. ncbi.nlm.nih.gov/books/NBK553175/

Dweik, R.A., Boggs, P.B., Erzurum, S.C., Irvin, C.G., Leigh, M.W., Lundberg, J.O., Olin, A.C., Plummer, A.L. and Taylor, D.R. (2011). An official ATS clinical practice guideline: Interpretation of exhaled nitric oxide levels (FENO) for clinical applications. Am. J. Respir. Crit. Care Med. 184: 601-615. https://doi.org/10.1016/j.ypdi. 2012.02.004

Eom, S.Y., Cho, E.B., Oh, M.K., Kweon, S.S., Nam, H.S., Kim, Y.D. and Kim, H. (2016). Increased incidence of respiratory tract cancers in people living near Portland cement plants in Korea. Int. Arch. Occup. Environ. Health 90: 859-864. https://doi.org/10.1007/s00420-017-1244-9

Fang, W., Yang, Y. and Xu, Z. (2013). $\mathrm{PM}_{10}$ and $\mathrm{PM}_{2.5}$ and health risk assessment for heavy metals in a typical factory for cathode ray tube television recycling. Environ. Sci. Technol. 47: 12469-12476. https://doi.org/10.1021/ es4026613

Fell, A.K.M., Sikkeland, L.I.B., Svendsen, M.V. and Kongerud, J. (2010). Airway inflammation in cement production workers. Occup. Environ. Med. 67: 395-400. https://doi.org/10.1136/oem.2009.047852

Fell, A.K.M., Noto, H., Skogstad, M., Nordby, K.C., Eduard, W., Svendsen, M.V., Ovstebo, R., Troseid, A. M.S. and Kongerud, J. (2011). A cross-shift study of lung function, exhaled nitric oxide and inflammatory markers in blood in Norwegian cement production workers. Occup. Environ. Med. 11: 799-805. https://doi.org/10.1136/oem.2010.05 7729

Ferris, B.G. (1978). Epidemiology Standardization Project (American Thoracic Society): II. Recommended respiratory disease questionnaires for use with adults and children in epidemiological research. Am. Rev. Respir. Dis. 118: 7-57.

Frank, T.L., Adisesh, A., Pickering, A.C., Morrison, J.F., Wright, T., Francis, H., Fletcher, A., Frank, P.I. and Hannaford, P. (1998). Relationship between exhaled nitric oxide and childhood asthma. Am. J. Respir. Crit. Care Med. 158: 1032-1036. https://doi.org/10.1164/ajrc cm.158.4.9707143

Frías, M., de Rojas, M.I.S., García, N. and Luxán, M.P. (1994). Contribution of toxic elements: Hexavalent chromium in materials used in the manufacture of cement. Cem. Concr. Res. 24: 533-541. https://doi.org/10.1016/0 008-8846(94)90142-2

Gizaw, Z., Yifred, B. and Tadesse T. (2016). Chronic respiratory symptoms and associated factors among cement factory workers in Dejen town, Amhara regional state, Ethiopia, 2015. Multidiscip. Respir. Med. 11: 13. https://doi.org/10.1186/s40248-016-0043-6

Goldsmith, D.F., Ruble, R.P. and Klein, C O. (1995). Comparative cancer potency for Silica ( $\mathrm{Si}$ ) from extrapolations of human and animal findings. Scand. J. 
Work Environ. Health 21: 104-107.

Greenberg, M.I., Waksman, J. and Curtis, J. (2007). Silicosis: A review. Dis. Mon. 53: 394-416. https://doi.org/10.1016/ j.disamonth.2007.09.020

Hutyrova, B., Smolkova, P., Nakladalova, M., Tichy, T. and Kolek, V. (2015). Case of accelerated silicosis in a sandblaster. Ind. Health 53: 178-183. https://doi.org/10.2 486/indhealth.2013-0032

International Agency for Research on Cancer (IARC). (1997). Silica, some silicates, coal dust and para-aramid fibrils. IARC Monographs on the Evaluation of Carcinogenic Risks to Humans Volume 68. International Agency for Research on Cancer.

International Agency for Research on Cancer (IARC). (2012). Arsenic, metals, fibres, and dusts: A review of human carcinogens. IARC Monographs on the Evaluation of Carcinogenic Risks to Humans Volume 100 C. International Agency for Research on Cancer

International Agency for Research on Cancer (IARC). (2019). Preamble. IARC Monographs on the identification of carcinogenic hazards to humans. https://monographs.ia rc.fr/wp-content/uploads/2019/01/Preamble-2019.pdf

Johns, P. and Pierce, R. (2008). Spirometry: The measurement and interpretation of ventilatory function in clinical practice. Australia: McGraw-Hill.

Jones Medical Instrument Company (2010). Easy Spirometry Interpretation Guide. http://www.jonesmedic al.com/spirometry $101 /$ what.asp

Junaid, M., Hashmi, M.Z., Malik, R.N. and Pei, D.S. (2016). Toxicity and oxidative stress induced by chromium in workers exposed from different occupational settings around the globe: A review. Environ. Sci. Pollut. Res. 23: 2015120167. https://doi.org/10.1007/s11356-016-7463-x

Kamaludin, N.H., Ahmad Razlan, N.S. and Jalaludin, J. (2018a). Association between respirable cement dust exposure and respiratory health among cement workers. Mal J. Med. Health Sci. 14: 78-86. https://medic.upm.ed u.my/upload/dokumen/2018120408594611_MJMHS_S P_Nov_2018.pdf

Kamaludin, N.H., Jalaludin, J., Mohd Tamrin, S.B. and Md Akim, A. (2018b). Biomarker of occupational airways inflammation for exposure to inorganic dust. Asian $J$. Agri. Biol. 6: 23-28. https://www.asianjab.com/biomarkerof-occupational-airways-inflammation-for-exposure-toinorganic-dust/

Kamaruddin, A.S., Jalaludin, J., Hamedon, T.R. and Hisamuddin, N.H. (2019). FeNO as a biomarker for airway inflammation due to exposure to air pollutants among school children nearby industrial areas in Terengganu. Pertanika J. Sci. Technol. 27: 589-600. http://www.pertanika.upm.edu.my/Pertanika\%20PAPER S/JST\%20Vol.\%2027\%20(2)\%20Apr.\%202019/03\%20J ST(S)-0477-2019.pdf

Key-Schwartz, R., Ramsey, D. and Schlecht, P. (2003). Silica, crystalline, by XRD (filter redeposition) (NIOSH Method 7500). Center for Disease Control, The National Institute for Occupational Safety and Health (NIOSH) http://www.cdc.gov/niosh/docs/2003-154/pdfs/7500.pdf

Kim, H.J., Choi, M.G., Park, M.K. and Seo, Y.R. (2017).
Predictive and prognostic biomarkers of respiratory disease due to particulate matter exposure. J. Cancer Prev. 22: 615. https://doi.org/10.15430/JCP.2017.22.1.6

Kim, S.H., Lee, C.G., Song, H.S., Lee, H.S., Jung, M.S., Kim, J.Y., Park, C.H., Ahn, S.C. and Yu, S.D. (2015). Ventilation impairment of residents around a cement plant. Ann. Occup. Environ. Med. 27: 3. https://doi.org/10. 1186/s40557-014-0048-6

Klemm, W.A. (1994). Hexavalent chromium in Portland cement. Cem. Concr. Aggreg. 16: 43-47. https://doi.org/1 0.1520/CCA10560J

Kuivenhoven, M. and Mason, K. (2019). Arsenic (Arsine) toxicity. StatPearls Publishing. https://www.ncbi.nlm.ni h.gov/books/NBK541125/

Lahiri, S., Levenstein, C., Nelson, D.I. and Rosenberg, B. (2005). The cost effectiveness of occupational health interventions: Prevention of silicosis. Am. J. Ind. Med. 48: 503-514. https://doi.org/10.1002/ajim.20222

Latif, M.T., Baharudin, N.H., Velayutham, P., Awang, N., Hamdan, H., Mohamad, R. and Mokhtar, M. (2011). Composition of heavy metals and airborne fibers in the indoor environment of a building during renovation. Environ. Monit. Assess. 181: 479-489. https://doi.org/10. 1007/s10661-010-1843-3

Maarsingh, H., Pera, T. and Meurs, H. (2008). Arginase and pulmonary disease. Naunyn Schmiedebergs Arch Pharmacol. 378: 171-184. https://doi.org/10.1007/s00210008-0286-7

Malaysia \& MDC Publishers Printers (1994). Factories and Machinery Act, 1967: Factories and machinery regulations: All amendments up to June 1994: Act 139 (6th ed.). Kuala Lumpur: MDC Publishers Printers.

Malaysia (2011). Occupational Safety and Health Act 1994 (ACT 514), Regulation and Order. Kuala Lumpur: International Law Book Services.

Malaysia (2012). Employment Act, 1955 (ACT 265), Regulation and Order. Kuala Lumpur: International Law Book Services.

Malaysia Competition Commission (MyCC) (2017). Annual report 2017: Promoting competition, protecting you. https://www.mycc.gov.my/sites/default/files/pdf/newsro om/MyCC\%20AR2017\%20BI.pdf

Malerba, M., Radaeli, A., Olivini, A., Damiani, G., Ragnoli, B., Montuschi, P. and Ricciardolo, F.L.M. (2014). BioMed Res. Int. 2014: 271918. https://doi.org/10.1155/2 014/271918

Manjula, R., Praveena, R., Clevin, R.R., Ghattargi, C.H., Dorle, A.S. and Lalitha, D.H. (2013). Effects of occupational dust exposure on the health status of portland cement factory workers. Int. J. Med. Pub. Health 3: 192-196. https://doi.org/10.4103/2230-8598.118963

Martin, R., Dowling, K., Pearce, D., Sillitoe, J. and Florentine, S. (2014). Health effects associated with inhalation of airborne arsenic arising from mining operations. Geosciences 4: 128-175. https://doi.org/10.3 390/geosciences 4030128

Mehraj, S.S., Bhat, G.A., Balkhi, H.M. and Gul, T. (2013). Health risks for population living in the neighbourhood of a cement factory. Afr. J. Environ. Sci. Technol. 7: 1044- 
1052. https://doi.org/10.5897/AJEST2013.1576

Mekasha, M., Haddis, A., Shaweno, T. and Mereta, S.T. (2018). Emission level of $\mathrm{PM}_{2.5}$ and its association with chronic respiratory symptoms among workers in cement industry: A case of Mugher cement industry, Central Ethiopia. Avicenna J. Environ. Health Eng. 5: 1-7. https://doi.org/10.15171/ajehe.2018.01

Meo, S.A. and Alshehri, M.K. (2014). Effect of exposure to cement dust on Fractional Exhaled Nitric Oxide (FENO) in non-smoking cement mill workers. Eur. Rev. Med. Pharmacol. Sci. 18: 1458-1464.

Merenu, I.A., Mojiminiyi, F., Bo, O., Njoku, C.H. and Ibrahim, M.T.O. (2007). The effect of chronic cement dust exposure on lung function of cement factory workers in Sokoto, Nigeria. Afr. J. Biomed. Res. 10: 139-143.

Mikoczy, Z. and Hagmar, L. (2005). Cancer incidence in the Swedish leather tanning industry: Updated findings 195899. Occup. Environ. Med. 62: 461-464. https://doi.org/1 0.1136/oem.2004.017038

Milson, M., Hull, R.D., Perkins, J.B., Wheeler, D.L., Nicholson, K. and Andrews, R. (2003). Elements by ICP (Nitric/Perchloric Acid Ashing) (NIOSH Method 7300). Center for Disease Control, The National Institute for Occupational Safety and Health (NIOSH). https://www.c dc.gov/niosh/docs/2003-154/pdfs/7300.pdf

Mishra, S. and Bharagava, R.N. (2016). Toxic and genotoxic effects of hexavalent chromium in environment and its bioremediation strategies. J. Environ. Sci. Health., Part C 34: 1-32. https://doi.org/10.1080/10590501.2015.1096883

Nakladalova, M., Stepanek, L., Kolek, V., Zurkova, M. and Tichy, T. (2018). A case of accelerated silicosis. Occup. Med. 68: 482-484. https://doi.org/10.1093/occmed/kqy106

National Institute for Occupational Safety and Health (NIOSH) (1998). NIOSH Environmental Surveillance Report Baker Concrete Construction.

National Institute for Occupational Safety and Health (NIOSH) (2018). Engineering Controls for Silica in Construction. https://www.cdc.gov/niosh/topics/silica/cu toffsaws.html

Nguyen, T.A., Park, J.W., Hess, M., Goins, M., Urban, P., Vaughan, J., Smith, A. and Hunt, J. (2005). Assaying all of the nitrogen oxides in breath modifies the interpretation of exhaled Nitric Oxide. Vasc. Pharmacol. 43: 379-384. https://doi.org/10.1016/j.vph.2005.08.003

Noor, H., Yap, C.L., Zulkepli, O. and Faridah, M. (2000). Effect of exposure to dust on lung function of cement factory workers. Med. J. Malaysia 55: 1-7.

Nordby, K.C., Fell, A.K.M., Noto, H., Eduard, W., Skogstad, M., Thomassen, Y., Bergamaschi, A., Kongerud, J. and Kjuus, H. (2011). Exposure to thoracic dust, airway symptoms and lung function in cement production workers. Eur. Respir. J. 38: 1278-1286. https://doi.org/10. 1183/09031936.00007711

Nordby, K.C., Noto, H., Eduard, W., Skogstad, M., Fell, A. K., Thomassen, Y., Skare, O., Bergamaschi, A., Pietroiusti, A., Abderhalden, R., Kongerud, J. and Kjuus, H. (2016). Thoracic dust exposure is associated with lung function decline in cement production workers. Eur. Respir. J. 48: 331-339. https://doi.org/10.1183/13993003.02061-2015
Occupational Safety and Health Administration (OSHA) (2010). Occupational Exposure to respirable crystalline silica -- Review of health effects literature and preliminary quantitative risk assessment. OSHA Publication. Washington DC. https://www.osha.gov/silica/Combined _Background.pdf

Ostrowski, S. and Barud, W. (2006). Factors influencing lung function: Are the predicted value for spirometry reliable enough? J. Physiol. Pharmacol. 4: 263-271.

Othman, M., Latif, M.T. and Mohamed, A.F. (2016). The $\mathrm{PM}_{10}$ compositions, sources and health risks assessment in mechanically ventilated office buildings in an urban environment. Air Qual. Atmos. Health 9: 597-612. https://doi.org/10.1007/s11869-015-0368-x

Oyinloye, M.A. (2015). Environmental Pollution and health risks of residents living near Ewekoro cement factory, Ewekoro, Nigeria. Int. J. Environ. Chem. Ecol. Geol. Geophys. Eng. 9: 108-114. https://doi.org/10.5281/zenod o.1099517

Pakhale, S., Bshouty, Z. and Marras, T.K. (2009). Comparison of percent predicted and percentile values for pulmonary function test interpretation. Can. Respir. J. 16: 190-194. https://doi.org/10.1155/2009/912185

Public Health England (2016). Compendium of chemical hazard: Inorganic Arsenic (As). https://webarchive.natio nalarchives.gov.uk/20170201154237/https://assets.publi shing.service.gov.uk/government/uploads/system/upload s/attachment_data/file/576933/arsenic_toxicological_ov erview.pdf

Rice, F.L., Park, R., Stayner, L., Smith, R., Gilbert, S. and Checkoway, H. (2001). Crystalline silica exposure and lung cancer mortality in diatomaceous earth industry workers: A quantitative risk assessment. Occup. Environ. Med. 58: 38-45. https://doi.org/10.1136/oem.58.1.38

Richard, E.E., Chinyere, N.A.A., Jeremaiah, O.S., Opara, U. C.A., Henrieta, E.M. and Ifunanya, E.D. (2016). Cement dust exposure and perturbations in some elements and lung and liver functions of cement factory workers. $J$. Toxicol. 4: 1-7. https://doi.org/10.1155/2016/6104719

Rodriguez-Cotto, R.I., Ortiz-Martinez, M.G., RiveraRamirez, E., Mateus, V.L., Amaral, B.S., Jimenez-Velez, B.D. and Gioda, A. (2014). Particle pollution in Rio de Janeiro, Brazil: Increase and decrease of pro-inflammatory cytokines IL-6 and IL-8 in human lung cells. Environ. Pollut. 194: 112-120. https://doi.org/10.1016/j.envpol.20 14.07.010

Smith, A.H., Ercumen, A., Yuan, Y. and Steinmaus, C.M. (2009). Increased lung cancer risks are similar whether arsenic is ingested or inhaled. J. Exposure Sci. Environ. Epidemiol. 19: 343-348. https://doi.org/10.1038/jes.2008.73

Stifelman, M. (2007). Using doubly-labeled water measurements of human energy expenditure to estimate inhalation rates. Sci. Total Environ. 373: 585-590. https://doi.org/10.1016/j.scitotenv.2006.11.041

Sulong, N.A., Latif, M.T., Khan, M.F., Amil, N., Ashfold, M.J., Abdul Wahab, M.I., Chan, K.M. and Sahani, M. (2017). Source apportionment and health risk assessment among specific age groups during haze and non-haze episodes in Kuala Lumpur, Malaysia. Sci. Total Environ. 
601-602: 556-570. https://doi.org/10.1016/j.scitotenv.20 17.05 .153

Tarlo, S.M., Cullinan, P. and Nemery, B. (2010). Occupational and environmental lung diseases: Diseases from work, home, outdoor and other exposure. Wiley Blackwell.

Tsai, J.H., Gu, W.T., Chung, I.I. and Chiang, H.L. (2019). Airborne air toxics characteristics and inhalation health risk assessment of a metropolitan industrial complex. Aerosol Air Qual. Res. 19: 2477-2489. https://doi.org/10. 4209/aaqr.2019.08.0422

Tungu, A.M., Bratveit, M., Mamuya, S.D. and Moen, B.E. (2013). Fractional exhaled nitric oxide among cement factory workers: A cross sectional study. Occup. Environ. Med. 70: 289-295. https://doi.org/10.1136/oemed-2012100879

Tungu, A.M., Bratveit, M., Mamuya, S.H. and Moen, B.E. (2014). Reduction in respiratory symptoms among cement workers: A follow-up study. Occup. Med. 65: 5760. https://doi.org/10.1093/occmed/kqu154

Tungu, A.M., Bratveit, M., Mamuya, S.H. and Moen, B.E. (2016). Cross-shift reduction in Fractional Exhaled Nitric Oxide among cement workers. Occup. Med. Health Aff. 4: 249. https://doi.org/10.4172/2329-6879.1000249

US Environmental Protection Agency (U.S. EPA) (1989). Risk-assessment guidance for superfund. Volume 1. Human health evaluation manual. Part A. Interim report (Final). Office of Emergency and Remedial Response US Environmental Protection Agency, Washington, DC.

US Environmental Protection Agency (U.S. EPA) (1995). Integrated Risk Information System (IRIS): Chemical assessment summary (arsenic), inorganic; CASRN 744038-2). https://cfpub.epa.gov/ncea/iris/iris_documents/docu ments/subst/0278_summary.pdf\#nameddest=cancerinhal

US Environmental Protection Agency (U.S. EPA) (1998). Integrated Risk Information System (IRIS): Chemical assessment summary (chromium VI); CASRN 18540-299. https://cfpub.epa.gov/ncea/iris/iris_documents/docum ents/subst/0144_summary.pdf\#nameddest=cancerinhal

US Environmental Protection Agency (U.S. EPA) (2011). Exposure Factors Handbook: 2011 Edition. National Center for Environmental Assessment, Office of Research and Development, Washington, DC, USA

US Environmental Protection Agency (U.S. EPA) (2012). Arsenic (As) compound. https://www3.epa.gov/airtoxic s/hlthef/Arsenic(As).html

US Environmental Protection Agency (U.S. EPA) (2015). Particulate matter. https://www.epa.gov/pm-pollution

US Environmental Protection Agency (U.S. EPA) (2018). Fundamentals of Indoor Air Quality in Buildings.

Wang, Y., Su, H., Gu, Y., Song, Xi., and Zhou, J. (2017). Carcinogenicity of chromium and chemoprevention: A brief update. Onco. Targets Ther. 10: 4065-4079. https://doi.org/10.2147/OTT.S139262

Whittaker, C., Rice, F., McKernan, L., Dankovic, D., Lentz, T.J., MacMahon, K., Kuempel, E., Zumwalde, R. and Schulte, P. (2017). NIOSH current intelligence bulletin 68: NIOSH chemical carcinogen policy. https://www.cdc. gov/niosh/docs/2017-100/pdf/2017-100.pdf

Widziewicz, K., Kozlowska, W.R. and Loska, K. (2016). Cancer risk from arsenic and chromium species bound to $\mathrm{PM}_{2.5}$ and $\mathrm{PM}_{1}-$ Polish case study. Atmos. Pollut. Res. 7: 884-894. https://doi.org/10.1016/j.apr.2016.05.002

Workers Health Protection Program (2013). Understanding your breathing test results. http://www.workers-health.or g/breathingtestresults.html

World Wild Foundation (WWF) (2008). A blueprint for a climate friendly cement industry. http://wwf.panda.org/w wf_news/?151621\%2FA-blueprint-for-a-climate-friendlycement-industry

Xu, X., Shang, Y., Tian, L., Weng, W. and Tu. J. (2019). Inhalation health risk assessment for the human Tracheobronchial Tree under PM exposure in a bus stop scene. Aerosol Air Qual. Res. 19: 1365-1376. https://doi.org/10.4209/aaqr.2018.09.0343

Yang, S.Y., Lin, J.M., Lin, W.Y. and Chang, C.W. (2018). Cancer risk assessment for occupational exposure to chromium and nickel in welding fumes from pipeline construction, pressure container manufacturing, and shipyard building in Taiwan. J. Occup. Health 60: 515524. https://doi.org/10.1539/joh.2018-0075-fs

Yatera, K., Morimoto, Y., Ueno, S., Noguchi, S., Kawaguchi, T., Tanaka, F., Suzuki, H. and Higashi, T. (2018). Cancer risks of hexavalent chromium in the respiratory tract. $J$. UOEH 40: 157-172. https://doi.org/10.7888/juoeh.40.157

Yeheyis, M., Aguilar, G., Hewage, K. and Sadiq, R. (2012). Exposure to crystalline silica ( $\mathrm{Si}$ ) inhalation among construction workers: A probabilistic risk analysis. Hum. Ecol. Risk Assess. 18: 1036-1050. https://doi.org/10.108 0/10807039.2012.707931

Zeleke, Z.K., Moen, B.E. and Bratveit, M. (2010). Cement dust exposure and acute lung function: A cross shift study. BMC Pulm. Med. 10: 19. https://doi.org/10.1186/1 471-2466-10-19

Zerguine, H., Jalaludin, J. and Mohd Tamrin, S.B. (2016). Behaviour-based safety approach and factors affecting unsafe behavior in construction sectors: A review. APEOHJ 2: 1-12.

Received for review, December 29, 2019 Revised, July 28, 2020 Accepted, September 21, 2020 